\title{
Análise da estrutura produtiva e do consumo de papéis tissue no Brasil
}

\author{
Lucas Ayres da Costa" \\ Carlos José Caetano Bacha***
}

\begin{abstract}
Resumo
Este artigo analisa a estrutura produtiva do segmento produtor de papéis tissue no Brasil (em especial, a sua concentração), destacando a evolução da produção e do consumo desses papéis no país. Para tanto, consideram-se dados de 1962 a 2015, dando atenção especial aos anos a partir de 1980. Partiu-se do paradigma estrutura-conduta-desempenho para ressaltar que aspectos daquele segmento estão sendo analisados, a saber: a sua estrutura de produção e as suas condições de demanda. A partir de dados coletados das associações que representam o segmento em análise e do Euromonitor, indicadores de concentração da produção (como o CR4, CR8 e HHI) foram calculados, bem como foram estimadas equações de demanda. Entre as conclusões do artigo, ressaltam-se: (1) no período de 1962 a 2015, a produção brasileira de papéis tissue cresceu à taxa geométrica anual de $7,48 \%$, frente ao crescimento de $5,71 \%$ a.a. da produção total de papéis. Consequentemente, a importância dos papéis tissue na produção total de papéis no Brasil passou de 4,2\%, em 1962, para 10,8\% em 2015; (2) devido a suas características de grande volume e baixo peso, o comércio exterior dos papéis tissue é pequeno, garantindo poder de mercado para as empresas aqui instaladas na fixação de preços; (3) há concentração regional na produção de papéis tissue, mas que tem reduzido ao longo do tempo; (4) a demanda desse produto é inelástica a preço e elástica a renda. As elasticidades preço e renda estimadas para o período de 1980 a 2015 foram de $-0,076$ e 1,671, respectivamente, mostrando que apesar de ser um produto de luxo, a demanda de papéis tissue é pouco sensível a variações de preços.
\end{abstract}

Palavras-chave: Demanda. Equações de demanda. Papéis tissue. Produção.

* Economista formado pela Esalq/USP. E-mail: lucas.ayres.costa@usp.br

** Professor Titular da Esalq/USP. E-mail: carlosbacha@usp.br

http://dx.doi.org/10.5335/rtee.v23i48.7362

Submissão: 25/01/2017. Aceite: 20/04/2017.

Teoria e Evidência Econômica - Ano 23, n. 48, p. 118-149, jan./jun. 2017 


\section{Introdução}

Papéis tissue são os destinados à higiene pessoal e à limpeza doméstica, tais como papel higiênico, papel-toalha, guardanapos, fraldas descartáveis, absorventes, entre muitos outros. Dependendo da exigência de qualidade do produto, fibras virgens (celulose) são utilizadas para sua fabricação ou, até mesmo, aparas recicladas de boa qualidade. Embora a maciez possa ser a propriedade mais importante dos papéis tissue, quando se fala em papel higiênico, outras propriedades também são importantes, como a sua resistência à tração, à umidade e a sua capacidade de absorção de líquidos.

Boa parte do consumo dos papéis tissue está ligado ao consumo dentro de casa, entretanto, o segmento fora de casa (away from home) tem ampliado sua demanda por esse produto (@Euromonitor International). Esse segmento é composto pelos usos de papéis tissue em restaurantes, hotéis, escritórios, escolas, os quais tendem a aumentar conforme a quantidade desses serviços cresça. O consumo dentro de casa de papéis tissue também tende a crescer conforme a renda e o nível de escolaridade da população aumentam, o que acaba por influenciar positivamente o aumento no consumo de produtos de higiene, como fraldas descartáveis, e de produtos mais luxuosos, como papéis higiênico premium.

Com a renda da população mundial crescendo, principalmente nos países emergentes, como China, Índia e Brasil, a demanda pelos papéis tissue tende também a crescer, o que leva ao aumento da sua produção mundial. Segundo dados da Food and Agriculture Organization of the United Nations (FAO), a produção mundial de papéis sanitários chegou a cerca de 32 milhões de toneladas em 2014, registrando uma taxa geométrica de crescimento de 4,58\% a.a. no período de 1961 a 2014. No Brasil, segundo dados da Indústria Brasileira de Árvores (Ibá), essa produção, em 2015, foi de aproximadamente 1.114.000 toneladas, registrando uma taxa geométrica de crescimento de 7,48\% a.a. no período de 1962 a 2015, enquanto que a taxa geométrica de crescimento da produção total de papéis do país, para 0 mesmo período, foi de $5,71 \%$ a.a. Outra forma de representar o crescimento relativo dos papéis tissue no cenário nacional é o fato de que, em 1962, a produção desses papéis no Brasil representava $4,2 \%$ da produção brasileira total de papéis e, em 2015 , essa porcentagem passou a ser de $10,8 \%$.

Em relação ao comércio exterior do produto, não se observam volumes expressivos de importação e de exportação pelo Brasil. Devido ao relativo baixo peso, ao alto volume e, consequente, aos altos custos de transporte, a produção orienta-se aos mercados consumidores mais próximos, fazendo com que a produção se volte 
mais para o mercado interno. Segundo dados da FAO, em 2013 as exportações brasileiras de papéis tissue totalizaram um valor de US $\$ 4,8$ milhões (referentes a 3.000 toneladas), e as importações totalizaram US $\$ 15,3$ milhões (referentes a 8.500 toneladas).

O consumo aparente da população brasileira por papéis tissue também segue tendência de alta, apresentando um salto no consumo per capita de $2,8 \mathrm{~kg} / \mathrm{ano} / \mathrm{ha}$ bitante em 1995 para 5,5 kg/ano/habitante em 2013 (ANFPC e Ibá). Apesar de esse consumo per capita estar próximo à média mundial, o país está abaixo do consumo de países desenvolvidos, como os Estados Unidos, o qual chega a consumir $23 \mathrm{~kg} /$ ano/habitante (@Euromonitor International). Isso expõe ainda mais o potencial que o setor ainda tem para crescer no Brasil à medida que a renda nacional aumente.

O segmento produtor de papéis tissue no Brasil tem peculiaridades em relação aos demais segmentos produtores de papéis. Segundo o trabalho de Mattos e Valença,

Uma das particularidades desse segmento é que boa parte da produção destina-se ao mercado consumidor final e não a outras indústrias, como no caso dos demais papéis. Esse fato exige dos produtores de tissue uma estrutura de comercialização voltada para o consumidor doméstico, fazendo com que a propaganda da marca e a logística sejam tão importantes quanto a produção industrial a baixo custo (1999, p. 266).

Considerando a importância atual e a perspectiva de bom crescimento no futuro da demanda por papéis tissue no Brasil, torna-se de grande importância o estudo da organização industrial desse segmento da indústria de papéis no Brasil, analisando o comportamento dos agentes produtores e consumidores que compõem o seu mercado.

De modo a contemplar essa necessidade, o objetivo geral deste artigo é analisar a estrutura do segmento produtor de papéis tissue no Brasil, em especial, a sua concentração, e a evolução da produção e do consumo de papéis tissue no Brasil. Consideram-se os anos de 1962 a 2015, em especial, aqueles a partir de 1980, para análise. A escolha desse período deve-se à disponibilidade de informações para as análises a serem realizadas.

Os objetivos específicos são: (a) analisar a estrutura do segmento em pauta por meio dos indicadores de concentração CR4, CR8 e HHI; (b) analisar a estrutura do segmento em pauta através dos dados da distribuição geográfica da sua produção; (c) analisar a evolução da produção, exportação, importação e consumo aparente de papéis tissue; (d) analisar a evolução do padrão de consumo de papéis tissue no Brasil ao longo do período em estudo; (e) analisar a participação do Brasil na produção mundial e no comércio internacional do produto; e (f) estimar a equação de demanda para o consumo de papéis tissue no Brasil. 
O artigo está organizado em mais cinco seções, além desta introdução. A seguir, apresenta-se uma revisão da literatura existente sobre o tema em análise, destacando, ao seu final, a contribuição deste artigo. A terceira seção apresenta o referencial analítico utilizado no estudo, seguida pela apresentação da metodologia e pela discussão dos dados utilizados no artigo (quarta seção). A quinta seção apresenta os resultados do artigo, seguidos das conclusões, apresentadas na sexta seção.

\section{Revisão da literatura}

A literatura disponível sobre a indústria e o mercado brasileiro de papéis, no que se associa aos objetivos deste artigo, pode ser agregada, no mínimo, em: (a) trabalhos que tratam do setor de celulose e papel em conjunto; (b) trabalhos que analisam a indústria de papéis como um todo; e (c) trabalhos que analisam os distintos segmentos produtores de papéis, incluindo o de papéis tissue.

No primeiro grupo - trabalhos que analisam o setor de celulose e papel como um todo - podem-se citar os trabalhos de Mattos e Valença (1999), International Labour Organization - ILO (2001), Sande (2002), Daura (2004), Ouchi (2006) e Montebello e Bacha $(2011 ; 2013)$. Tratando de diferentes períodos de tempo e com atenção a diferentes tópicos, esses trabalhos mostram a evolução diferenciada das produções de celulose e de papéis no Brasil, com a primeira direcionando-se crescentemente, desde a década de 1970, para o mercado externo, enquanto a segunda orienta-se para o mercado doméstico. O Estado, em especial, através da atuação do BNDES, exerceu papel crucial para o crescimento desse setor, seja através de empréstimos subsidiados e/ou pela participação acionária nas empresas. Tem ocorrido, ainda que com composição diferente ao longo do tempo, a atuação conjunta, mas independente, de empresas nacionais e internacionais nesse setor. Os trabalhos ressaltam ainda aspectos como o cumprimento de legislação ambiental pelo setor, a integração vertical do mesmo (em especial, das fabricantes de celulose com a sua base florestal), os avanços tecnológicos distintos entre as indústrias do setor (determinando sua competitividade internacional) e os impactos da globalização sobre o setor em análise.

Abordando especificamente as indústrias de papéis no Brasil, sobressaem-se os trabalhos de Carazza e Bacha (2004) e Montebello e Bacha (2015). Esses trabalhos destacam os diferentes segmentos que compõem a indústria de papéis no Brasil, suas evoluções e concentrações distintas. Eles são importantes ao mostrar os crescimentos distintos dos diferentes segmentos produtores de papéis, suas distintas concentrações, integrações verticais e orientação para o mercado (doméstico ou externo) de suas produções. Por exemplo, o trabalho de Carazza e Bacha (2004), considerando 
o período de 1965 a 2003, evidencia que há diferenças estruturais entre os segmentos da indústria de papéis (papéis de embalagem, papéis de imprimir, papéis de escrever, papel cartão, papéis para fins sanitários, papel imprensa e papéis especiais) e que a indústria como um todo tem ampliado sua concentração ao longo do tempo. Porém, isso não implica idêntico acréscimo de poder de mercado na fixação de preços, pois a abertura comercial atenua esse poder (MONTEBELLO; BACHA, 2015).

Tratando individualmente dos segmentos dentro da indústria de papéis têm-se os trabalhos de: Silva (2002), Silva (2003) e Aranha e Bacha (2011), abordando o segmento produtor de papéis de imprimir e escrever; Cabrini e Bacha (2011) e Manfio (2015), tratando do segmento produtor de papéis de embalagem da linha marrom; e Macedo e Leite (1997), tratando do segmento produtor de papéis tissue. Os cinco primeiros trabalhos citados nesse parágrafo avaliam, usando dados coletados por associações representativas do setor de celulose e papel, as evoluções de suas produções, suas exportações e importações, e sua concentração industrial, fazendo uso dos tradicionais indicadores CR4, CR8 e HHI. Os trabalhos de Aranha e Bacha (2011) e de Cabrini e Bacha (2011) também realizam uma valoração da cadeia produtiva dos segmentos produtores de papéis de imprimir e escrever e de kraftliner, respectivamente, evidenciando o quanto se acrescenta de valor em cada elo dessas cadeias.

O trabalho de Macedo e Leite (1997) examina, usando dados de 1985 a 1996, o comportamento da produção, do consumo e da comercialização de papéis para fins sanitários (papéis tissue), destacando o crescimento mais acelerado de seu consumo no Brasil do que no resto do mundo. O consumo de papéis tissue no mundo cresceu à taxa $3,6 \%$ a.a., no período de 1990 a 1996, e à taxa de $8 \%$ a.a. no Brasil entre 1993 e 1996.

O presente artigo não inova em relação à literatura revisada ao considerar a análise da estrutura de produção de papéis tissue, pois emprega a mesma metodologia e indicadores já considerados na literatura abordada. No entanto, tratará de um período diferente do analisado em outros trabalhos, mais recente, o que permitirá comparar os nossos resultados com o de outros artigos. Mas, ao tratar da análise da demanda, em especial, da interna, por papéis tissue, o presente artigo traz grande contribuição.

\section{Referencial analítico}

O paradigma "Estrutura, Conduta e Desempenho" (ver Figura 1) é o principal referencial analítico que fundamenta as análises feitas neste artigo sobre o mercado de papéis tissue no Brasil. Segundo Carlton e Perloff (2005), existem ao 
menos duas abordagens para o estudo da organização industrial. A primeira delas, o paradigma "Estrutura, Conduta e Desempenho", é essencialmente descritiva e proporciona uma "visão geral" da organização industrial. A segunda abordagem, a qual os autores chamam de "teoria do preço", é elaborada a partir de modelos microeconômicos que buscam explicar a conduta das firmas e a estrutura do mercado.

Figura 1 - O paradigma "Estrutura, Conduta e Desempenho"

\section{Condições Básicas \\ - Demanda e Produção \\ -Elasticidades da demanda, Bens Substitutos, Tecnologia, Economia de escala e de escopo}

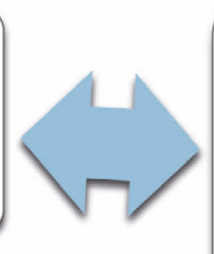

\section{Estrutura}

- Número de compradores e vendedores

- Barreiras à entrada de novas firmas

- Integração vertical

- Diferenciação dos produtos e diversificação

\section{Desempenho}

-Preço

-Eficiência produtiva e de alocação de recursos

-Qualidade do produto

- Progresso tecnológico

- Lucro

\section{Conduta}

- Propagandas

- Pesquisa e desenvolvimento

- Estratégia e determinação de preços

- Manobras legais

- Conluio

- Fusões e contratos

Fonte: adaptado de Carlton e Perloff (2005).

De acordo com a abordagem do paradigma "Estrutura, Conduta e Desempenho", o desempenho ou performance de uma indústria (mensurado por variáveis como preço, eficiência produtiva, qualidade e lucro) depende da conduta ou do comportamento de suas firmas (avaliadas pelas práticas de propaganda, determinação de preço, fusões, por exemplo), e essa conduta depende da estrutura do mercado em que estão inseridas essas firmas. Essa estrutura, por sua vez, depende das condições básicas do mercado, tais como as características da demanda (elasticidades, existência de bens substitutos) e da produção (tecnologia, matéria-prima, economias de escala e de escopo).

Ressalta-se que não há apenas uma única relação unidirecional de a estrutura determinar a conduta e essa, o desempenho. Por exemplo, práticas de fusões 
(elemento da conduta) podem levar à formação de oligopólios ou monopólios e de barreiras à entrada, modificando a estrutura do mercado. Essa última, por sua vez, pode incentivar a criação e a produção de novos bens substitutos que afetarão a demanda do mercado do produto original.

O presente artigo considera, na sua análise, alguns aspectos do paradigma "Estrutura, Conduta e Desempenho", pois maior atenção é dada às questões de estrutura e das condições básicas de demanda do segmento produtor de papéis tissue. Procura-se estimar as elasticidades de preço e renda da demanda de papéis tissue no Brasil, o que ainda não foi feito.

\section{Metodologia e dados utilizados}

\subsection{Metodologia}

Para análise da estrutura do mercado do segmento produtor de papéis tissue são utilizados dados de produção e de vendas que permitem o cálculo dos indicadores de concentração CR4, CR8 e HHI. O CR4 representa a participação, em porcentagem, dos quatro principais produtores no total produzido pelo setor, pela indústria ou pelo segmento produtor do mercado em análise. Esse indicador também pode ser calculado com base na participação nas vendas de cada empresa sobre $o$ total comercializado. Em termos matemáticos, o CR4 pode ser calculado através da seguinte fórmula: $C R(4)=\sum_{i=1}^{4} \frac{Q i}{Q t}$, em que $Q i$ equivale ao total produzido ou vendido pelo produtor $i$; e Q $t$ equivale ao total produzido ou vendido no mercado.

O critério de avaliação do grau de concentração do mercado é o mesmo utilizado por Leite (1998) apud Carrazza e Bacha (2004), e apresentado no Quadro 1.

Quadro 1 - Classificações dos graus de concentração da indústria de acordo com o $\mathrm{CR}(4)$

\begin{tabular}{|l|l|}
\hline \multicolumn{1}{|c|}{ CR(4) } & \multicolumn{1}{c|}{ Grau de Concentração } \\
\hline $75 \%$ ou mais & Muito Alto \\
$65 \%$ a $75 \%$ & Alto \\
$50 \%$ a $65 \%$ & Moderadamente Alto \\
$35 \%$ a $50 \%$ & Moderadamente Baixo \\
$35 \%$ ou menos & Baixo \\
\hline
\end{tabular}

Fonte: adaptado de Leite (1998). 
A metodologia de cálculo do CR8 é similar à do cálculo do CR4, sendo que no primeiro se consideram os oito maiores produtores. O HHI, abreviação de Herfindahl-Hirshman Index, equivale à soma dos quadrados da participação na produção ou nas vendas de cada produtor. Em termos matemáticos, o HHI pode ser calculado pela seguinte fórmula: $H H I=\sum_{i=1}^{n}\left(\frac{Q i}{Q t}\right)^{2}$. Tal como anteriormente, $Q i$ é o total produzido ou vendido pelo produtor $i$; $\mathrm{Q} t$ é o total produzido ou vendido no mercado; e $n$ é o número total de produtores do setor.

O HHI é mais utilizado como indicador de desigualdade, ou seja, mensura o quanto a produção está mais ou menos distribuída igualitariamente entre os produtores. Esse indicador varia entre 0 e 1, em que o valor 1 indica que toda a produção pertence a um único produtor e um valor mais próximo de 0 indica a presença de grande número de produtores e uma produção mais igualitariamente distribuída entre eles.

Para avaliar o crescimento de séries históricas de dados foi utilizado o conceito de taxa geométrica de crescimento anual (TGCA), que é calculada da seguinte forma: (1) tomam-se os logaritmos naturais de cada observação para cada ano em análise; (2) depois se estima uma equação linear simples, sendo que a variável dependente é o logaritmo natural da produção (ou do consumo) e a variável explicativa é o tempo: $\operatorname{Ln}($ dado $)=a+b$.tempo; (3) feita a regressão linear simples e estimado o coeficiente angular "b", toma-se o antilog do valor de b e subtrai-se dele o valor 1 , obtendo assim a taxa geométrica de crescimento anual (TGCA): $e^{b}-1=T G C A$.

O cálculo do consumo aparente é usado para se tentar mensurar o quanto de um produto é consumido em uma região, quando não há precisamente dados de consumo ou do quanto foi realmente comprado por consumidores finais daquele produto, mas existem dados sobre a produção, a exportação e a importação daquele produto. Esperando que toda a produção interna, assim como as importações, sejam efetivamente consumidas e excluindo da produção a parte que é exportada, chega-se ao consumo aparente daquele produto através da seguinte equação:

Consumo aparente $=$ Produção total - Exportações + Importações

Dados de exportação e de importação de papéis tissue são importantes para avaliar a participação dessa atividade produtiva no comércio exterior do Brasil, o que é fator fundamental para avaliar a contestabilidade do segmento produtor de papéis tissue da indústria brasileira de papéis e para entender sua estrutura competitiva. 
Através da evolução dos dados sobre consumo, é possível avaliar o aumento da importância da atividade produtora de papéis tissue para a sociedade, em especial, avaliar as mudanças no perfil de consumo do brasileiro dentro da própria indústria de papéis tissue, que vem migrando de produtos de menor qualidade para os de maior qualidade.

Para a estimação de uma função de demanda para o consumo aparente de papéis tissue no Brasil, foram elaborados quatro modelos econométricos (Quadro 2) que, após estimados, considerando dados de 1980 a 2015, permitem identificar aquele que apresenta os resultados mais robustos em termos estatísticos. Os modelos são calculados na forma de regressões lineares múltiplas, buscando valorar os impactos dos preços e, principalmente, da renda da população brasileira na demanda por papéis tissue no país. Para cada modelo, também foram realizadas estimações fazendo transformações logarítmicas dos dados utilizados, gerando um total prévio de oito regressões a serem rodadas. No entanto, mais três regressões foram realizadas, a fim de corrigir problemas de heterocedasticia e de autocorrelação dos resíduos, gerando, ao final, um total de onze regressões realizadas e comentadas no item 5.6.

Não existem dados disponíveis sobre os preços dos tipos de papéis tissue comercializados no Brasil, em uma abrangência nacional, para uma série histórica suficientemente longa que permita a estimação de uma função demanda estatisticamente robusta. Logo, para incluir a variável preço nos modelos, foi tomado o preço médio das exportações brasileiras de papéis tissue no período de 1980 a 2015, obtido da divisão do valor em dólares recebidos dessas exportações pela quantidade exportada em toneladas e da transformação desses valores em reais constantes de 2015 por meio de taxas de câmbio médias anuais e do índice de inflação, segundo o IGP-DI. Os preços obtidos por meio desses cálculos podem ser considerados como preços internos, devido aos valores das exportações utilizados no cálculo serem o valor recebido pelos exportadores brasileiros em termos FOB (free on board). E, como será apresentado nos itens 5.1 e 5.2 da seção 5 , os preços dos produtos tissue não são determinados no comércio internacional, devido à baixa participação das quantidades exportadas sobre as quantidades produzidas, fenômeno que se observa tanto no Brasil, quanto na grande maioria dos países.

Quadro 2 - Modelos de funções demanda para consumo de papéis tissue no Brasil

\begin{tabular}{|c|c|}
\hline 1ㅇ Modelo & $Q d_{t}=\alpha_{0}+\alpha_{1}$ preço $_{t}+\alpha_{2}$ renda $_{t}$ \\
\hline 2o Modelo & $Q d_{t}=\alpha_{0}+\alpha_{1}$ preço $_{t}+\alpha_{2}$ renda $_{t}+\alpha_{3} D$ \\
\hline 3으odelo & $Q d_{t}=\alpha_{0}+\alpha_{1}$ preço $_{t}+\alpha_{2}$ renda $_{t}+\alpha_{3} Q_{t-1}$ \\
\hline $4^{\circ}$ Modelo & $Q d_{t}=\alpha_{0}+\alpha_{1}$ preço $_{t}+\alpha_{2}$ renda $_{t}+\alpha_{3} D+\alpha_{4} Q_{t-1}$ \\
\hline
\end{tabular}


Em que: $Q d_{t}$ é a variável dependente do modelo e é o consumo aparente brasileiro de papéis tissue no ano $t$; preço é o preço médio das exportações brasileiras de papéis tissue no ano $t$; renda $a_{t}$ é o valor do PIB brasileiro, usado como uma aproximação da renda no ano $t$; $D$ é a variável tendência; e $Q_{t-1}$ é o consumo brasileiro de papéis tissue no ano $t-1$ (defasado em um ano).

Espera-se que o coeficiente associado à variável preço, nas regressões do Quadro 2 , tenha sinal negativo, e os demais coeficientes tenham sinais positivo.

\subsection{Dados utilizados}

Dados gerais sobre produção e vendas por tipo de papéis tissue são utilizados em conjunto, oriundos das seguintes fontes:

- Relatórios estatísticos anuais da antiga ANFPC (Associação Nacional dos Fabricantes de Papel e Celulose). Esses relatórios fornecem dados sobre produção por tipos de papéis tissue, segundo seus produtores e sua localização no período de 1980 a 1996.

- Relatórios estatísticos anuais da Bracelpa (Associação Brasileira de Celulose e Papel). Esses relatórios oferecem dados sobre produção e vendas por tipos de papéis tissue, segundo seus produtores e sua localização no período de 1998 a 2014. Entretanto, os dados mais detalhados sobre produção de papéis tissue, separados em tipos, deixaram de ser divulgados a partir de 2011, e os dados de produtores e sua localização deixaram de ser divulgados a partir de 2006 (o que dificulta o cálculo dos indicadores de concentração), sendo divulgados apenas dados de produção e de vendas totais desses papéis por ano.

- Relatórios estatísticos da Ibá. Esses relatórios oferecem dados totais de produção e de vendas de papéis tissue no período de 2014 a 2015.

- Dados da produção mundial e do comércio exterior mundial de papéis tissue disponibilizados pela FAO no período de 1962 a 2014.

ANFPC, Bracelpa e Ibá são instituições que se sucederam ao longo do período analisado, portanto, é possível utilizar as séries de dados gerados por elas de forma integrada, pois a metodologia da coleta é a mesma.

Como mencionado anteriormente, dados mais detalhados sobre produção e venda de papéis tissue separados por tipo e produtores deixaram de ser divulgados a partir de 2006, dificultando os cálculos dos indicadores de concentração do segmento produto a de papéis tissue e uma análise mais detalhada da produção dos vários tipos de papéis tissue. Para suprir essa carência, são utilizados os dados 
fornecidos pela @Euromonitor, os quais permitem os cálculos dos indicadores de concentração e detalham as vendas do segmento em diferentes tipos de papéis tissue, no período de 2000 a 2014 . Cabe a ressalva de que os dados da @Euromonitor não podem ser utilizados de forma integrada aos dados das fontes citadas anteriormente por questões metodológicas, porém, eles auxiliam na análise da atividade em questão, no período mais recente.

\section{Resultados e análise}

Esta seção apresenta os resultados da pesquisa que contempla os objetivos específicos listados anteriormente. Inicialmente, no item 5.1, há a análise da evolução, ao longo dos anos de 1962 a 2014, da produção mundial de papéis tissue e de seu comércio internacional, situando o Brasil nesse segmento produtor. No item 5.2, apresenta-se a evolução da produção, da exportação, da importação e do consumo aparente de papéis tissue no Brasil, destacando a orientação da produção brasileira do produto em apreço. No item 5.3, analisa-se a estrutura do segmento produtor de papéis tissue no Brasil, calculando e interpretando os indicadores de concentração e de desigualdade, sugeridos no item 4.1 e avaliados por grupos empresariais. A distribuição regional da produção de papéis tissue no Brasil é analisada no item 5.4. No item seguinte, analisa-se a evolução da produção e do consumo dos tipos distintos de papéis tissue. Por fim, no item 5.6, apresenta-se as estimativas das regressões de consumo de papéis tissue no Brasil e os cálculos de suas elasticidades.

\subsection{Produção de papéis tissue no mundo e seu comércio internacional}

Ao longo de todo o período de 1962 a 2014, com exceção apenas dos anos de 1975 e 1993, a produção mundial de papéis tissue sempre foi crescente (Figura 2). Registrando uma TGCA de 4,58\% no período, essa produção cresceu mesmo em tempos de crise econômica mundial, como a que ocorreu no ano de 2008, o que torna sua demanda e, consequentemente, sua produção mais resistente, porém, não imune às crises econômicas. 
Figura 2 - Produção mundial de papéis tissue no período de 1962 a 2014 (valores em mil toneladas)

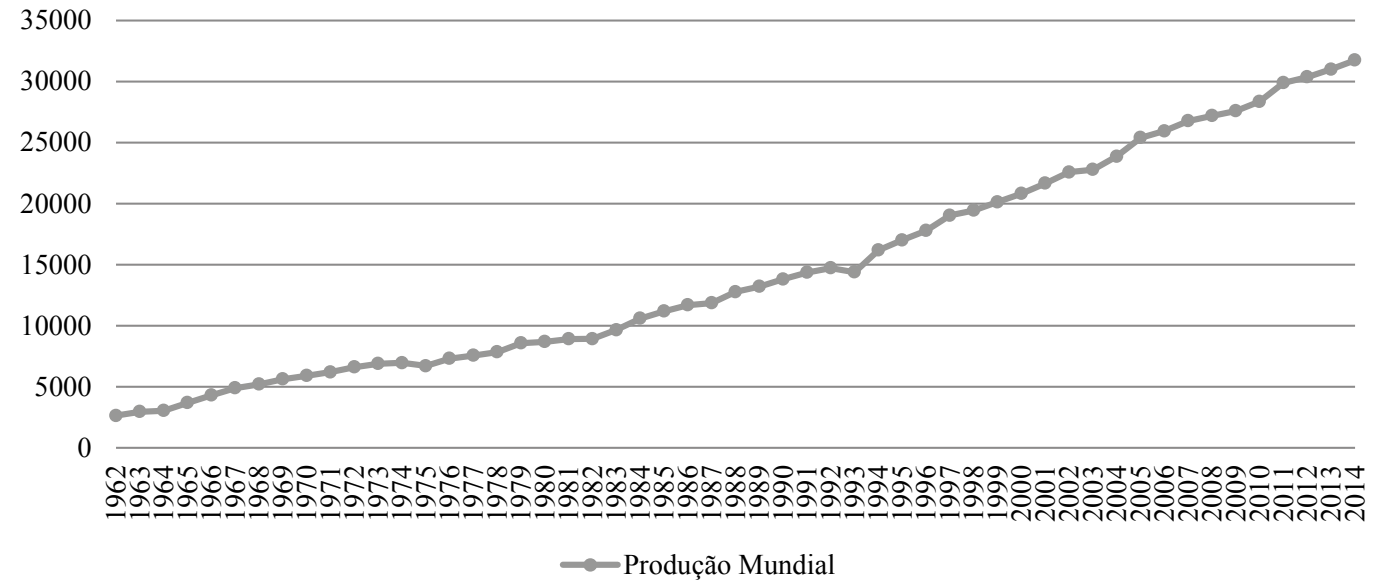

Fonte: FAOSTAT (2016).

A produção mundial de papéis tissue registrou, em 2014, último dado disponível na época de elaboração do presente estudo, um total de 32 milhões de toneladas. A China e os Estados Unidos são seus grandes países produtores, distanciando-se com larga margem dos demais (Tabela 1). Os chineses ultrapassaram a produção estadunidense somente a partir de 2011, porém, ao longo do período analisado, vinha consistentemente caindo a participação dos EUA na produção mundial, devido, principalmente, ao rápido crescimento da produção chinesa. Em 2014, a China respondeu por $26,15 \%$ da produção mundial de papéis tissue, e os EUA, por 21,20\%. Em 1990, essas percentagens foram de 6,26\% e 38,10\%, respectivamente.

O Brasil, historicamente, tem uma participação importante na produção mundial de papéis tissue, colocando-se, consistentemente, entre os dez principais produtores e apresentando uma tendência de ascendência na sua classificação, com exceção do período de 1990 a 2000, em que sua classificação caiu, porque sua produção aumentou a uma taxa menor do que a dos demais países. Em 2014, o Brasil retomou sua melhor classificação entre os principais países produtores de papéis tissue, ficando em sexto lugar e produzindo um total de 1,1 milhão de toneladas (Tabela 1).

O fato de os papéis tissue ocuparem um grande volume e terem baixo peso (RISI, 2015), faz a comercialização internacional do produto se limitar a países vizinhos, tornando mais difícil um país ser grande nas exportações ou nas importações sobre o total produzido. Somando o fato dos papéis tissue também serem de um relativo baixo valor agregado por unidade, os custos de comercialização 
internacional acabam tornando o consumo doméstico mais vantajoso. Isso também faz com que a maioria dos papéis tissue exportados seja em formato ainda virgem (RISI, 2015), ou seja, ainda restam processos de transformação para se chegar ao produto finalizado. Por conta disso, entre os anos de 1970 e 1990, as importações e as exportações de papéis tissue correspondiam, em média, a 5,1\% do total produzido mundialmente. Entretanto, ao calcular a TGCA das quantidades exportadas e importadas, verifica-se que elas cresceram a uma taxa anual de $7,75 \%$ no período de 1970 a 2014, cerca de três pontos percentuais maiores do que a TGCA da produção mundial. Esse crescimento foi ainda maior a partir dos anos 2000, fazendo com que a mesma porcentagem média das exportações e das importações sobre a produção mundial, no período de 2000 a 2014 , saltasse para $7,9 \%$.

Tabela 1 - Participação dos principais países produtores de papéis tissue na produção mundial (os dados, na linha mundo, são o total produzido mundialmente em toneladas)

\begin{tabular}{|c|c|c|c|c|c|c|c|c|c|c|c|}
\hline \multicolumn{2}{|c|}{1970} & \multicolumn{2}{|c|}{1980} & \multicolumn{2}{|c|}{1990} & \multicolumn{2}{|c|}{2000} & \multicolumn{2}{|c|}{2010} & \multicolumn{2}{|c|}{2014} \\
\hline Países & Particip. $(\%)$ & Países & Particip.(\%) & Países & Particip.(\%) & Países & Particip. (\%) & Países & Particip. (\%) & Países & Particip.(\%) \\
\hline EUA & 57,09 & EUA & 45,64 & $\overline{E U A}$ & 38,10 & EUA & 30,12 & EUA & 23,39 & China & 26,15 \\
\hline Japão & 8,45 & Japão & 10,35 & Japão & 9,89 & China & 12,01 & China & 21,87 & EUA & 21,20 \\
\hline Reino Unido & 4,97 & Alemanha & 5,92 & China & 6,26 & Japão & 8,34 & Japão & 6,32 & Japão & 5,56 \\
\hline Alemanha & 4,60 & Reino Unido & 4,99 & Alemanha & 6,00 & Itália & 5,85 & Itália & 4,90 & Alemanha & 4,53 \\
\hline Canadá & 3,69 & Canadá & 3,73 & Canadá & 3,38 & Alemanha & 4,89 & Alemanha & 4,74 & Itália & 4,37 \\
\hline Suécia & 2,89 & $\underline{\operatorname{Brasil}\left(6^{\circ}\right)}$ & 2,67 & Reino Unido & 3,19 & Reino Unido & 3,48 & México & 3,52 & Brasil( $\left.6^{\circ}\right)$ & $\underline{3.53}$ \\
\hline Itália & 2,61 & Suécia & 2,64 & México & 2,79 & México & 3,32 & Brasil $\left(7^{\circ}\right)$ & $\underline{3,19}$ & México & 3,41 \\
\hline França & 2,36 & França & 2,13 & $\underline{\operatorname{Brasil}\left(8^{\circ}\right)}$ & $\underline{2,72}$ & Canadá & 3,13 & Canadá & $\overline{2,57}$ & França & 2,58 \\
\hline Finlândia & 1,69 & México & 2,12 & Itália & 2,55 & $\underline{\operatorname{Brasil}\left(9^{\circ}\right)}$ & 2,87 & Reino Unido & 2,57 & Reino Unido & 2,42 \\
\hline Holanda & 1,18 & Polônia & 1,92 & França & 2,32 & França & $\overline{2,78}$ & França & 2,57 & Espanha & 2,23 \\
\hline Austrália & 1,09 & Finlândia & 1,58 & Suécia & 2,05 & Espanha & 2,08 & Espanha & 2,52 & Canadá & 2,22 \\
\hline Áustria & 0,98 & Itália & 1,47 & Espanha & 1,68 & Suécia & 1,50 & Coréia do Sul & 1,57 & Coréia do Sul & 1,67 \\
\hline Brasil $\left(1^{\circ}\right)$ & 0,97 & Espanha & 1,43 & Coréia do Sul & 1,42 & Taiwan & 1,48 & Indonésia & 1,47 & Indonésia & 1,36 \\
\hline Mundo & 5.908 .500 & Mundo & 8.696 .100 & Mundo & 13.817 .400 & Mundo & 20.815 .308 & Mundo & 28.353 .888 & Mundo & 31.745 .396 \\
\hline
\end{tabular}

Fonte: baseado em FAOSTAT 2016.

Em 2014, cerca de 3 milhões de toneladas de papéis tissue foram comercializadas internacionalmente, valor que corresponde a $9,51 \%$ da produção mundial no mesmo ano (tabelas 2 e 3). A Alemanha é o principal país importador e também exportador desse tipo de papel. A razão para seu destaque nas duas estatísticas é que a maioria do volume importado pelo país é transitória, para ser transformada e exportada novamente, devido à carência de empresas transformadoras em países próximos, como a Hungria (RISI, 2015).

O Brasil, como será melhor analisado nos próximos itens, tem participação muito pequena no comércio internacional de papéis tissue, tanto em exportações, quanto em importações (Tabelas 2 e 3). 
Tabela 2 - Exportações mundiais de papéis tissue no mundo e em países selecionados (1970 a 2014) (valores deflacionados a dólares constantes de 2014)

\begin{tabular}{|c|c|c|c|c|c|c|c|c|c|c|c|c|}
\hline \multicolumn{4}{|c|}{1970} & \multicolumn{4}{|c|}{1980} & \multicolumn{5}{|c|}{1990} \\
\hline Paises & \begin{tabular}{l|l} 
Quant.(t) & $\mathrm{V}_{\mathrm{a}}$ \\
\end{tabular} & \begin{tabular}{l|l} 
Valor(mil US\$) & Part \\
\end{tabular} & articip. $(\%)$ & Países & Quant.(t) & Valor(mil US\$) & Partici.(\%) & \multicolumn{2}{|l|}{ Países } & Quant.(t) & \begin{tabular}{l|l} 
(t) & Valor(mil US\$) \\
\end{tabular} & \begin{tabular}{l|l|} 
Particip. $(\%)$ \\
\end{tabular} \\
\hline Finlândia & 71.400 & 152.377 & 28,58 & Finlândia & 56.500 & 138.732 & 13,97 & \multicolumn{2}{|l|}{ Itália } & 114.000 & 297.805 & 13,17 \\
\hline Itália & 35.100 & 139.446 & 14,05 & EUA & 55.300 & 153.767 & 13,67 & \multicolumn{2}{|c|}{ Alemanha } & 112.400 & 286.198 & 12,99 \\
\hline Suécia & 34.600 & 59.700 & 13,85 & Suécia & 49.500 & 150.405 & 12,24 & \multicolumn{2}{|c|}{ Bélgica-Luxemburgo } & 94.200 & 305.764 & 10,89 \\
\hline Alemanha & 21.900 & 85.520 & 8,77 & Canadá & 44.200 & 98.361 & 10,93 & \multicolumn{2}{|c|}{ Suécia } & 89.500 & 286.857 & 10,34 \\
\hline EUA & 18.000 & 51.616 & 7,21 & Tchecoslováquia & 37.300 & 82.168 & 9,22 & \multicolumn{2}{|l|}{ Canadá } & 85.500 & 162.971 & 9,88 \\
\hline Canadá & 16.300 & 27.978 & 6,53 & Alemanha & 35.000 & 111.723 & 8,65 & \multicolumn{2}{|l|}{ Finlândia } & 78.000 & 177.498 & 9,01 \\
\hline Noruega & 12.000 & 26.436 & 4,80 & Bélgica-Luxemburgo & 23.500 & 75.851 & 5,81 & \multicolumn{2}{|l|}{ França } & 47.700 & 154.009 & 5,51 \\
\hline Iugoslávia & 11.200 & 16.437 & 4,48 & França & 18.700 & 68.091 & 4,62 & \multicolumn{2}{|l|}{ Súca } & 41.000 & 109.080 & 4,74 \\
\hline Holanda & 9.000 & 16.943 & 3,60 & África do Sul & 16.000 & 36.829 & 3,96 & \multicolumn{2}{|l|}{ EUA } & 32.400 & 74.769 & 3,74 \\
\hline França & 7.000 & 22.558 & 2,80 & Holanda & 14.500 & 51.688 & 3,58 & \multicolumn{2}{|c|}{ Tchecoslováquia } & 30.000 & 56.168 & 3,47 \\
\hline Brasil & N/D & $\mathrm{N} / \mathrm{D}$ & $\mathrm{N} / \mathrm{D}$ & Brasil $\left(17^{\circ}\right)$ & 3.200 & 11.116 & 0,79 & \multicolumn{2}{|c|}{ Brasil $\left(16^{\circ}\right)$} & 9.600 & 17.240 & 1,11 \\
\hline Mundo & 249.800 & 643.249 & 100 & Mundo & 404.500 & 1.175 .949 & 100 & \multicolumn{2}{|l|}{ Mundo } & 865.300 & 2.235 .692 & 100 \\
\hline & & 2000 & & & & 010 & & & & & 2014 & \\
\hline Países & Quant.(t) & Valor(mil US\$) & \begin{tabular}{l|l} 
\$) & Particip. (\%) \\
\end{tabular} & Países & Quant.(t) & Valor(mil US\$) & Particip.(\%) & Países & & ant. $(\mathrm{t})$ & \begin{tabular}{|l|l} 
Valor(mil US\$) & $\mathrm{P}$ \\
\end{tabular} & Particip.(\%) \\
\hline Itália & 167.000 & 229.647 & 11,82 & Indonésia & 272.616 & 329.087 & 13,28 & Alemanha & & 0.000 & 1.585 .339 & 22,52 \\
\hline EUA & 130.000 & 241.603 & 9,20 & Itália & 272.250 & 406.783 & 13,26 & Itália & & 9.874 & 453.048 & 11,26 \\
\hline Alemanha & 110.000 & 198.628 & 7,79 & EUA & 174.000 & 229.076 & 8,48 & Indonésia & & 2.283 & 353.188 & 10,01 \\
\hline México & 95.600 & 79.954 & 6,77 & Canadá & 140.000 & 228.585 & 6,82 & China & & 3.090 & 342.816 & 7,39 \\
\hline Suécia & 95.330 & 209.949 & 6,75 & Suécia & 130.032 & 310.267 & 6,33 & Turquia & & 7.342 & 194.963 & 5,21 \\
\hline Canadá & 94.798 & 154.576 & 6,71 & Eslováquia & 117.906 & 352.918 & 5,74 & EUA & & 9.729 & 206.601 & 4,96 \\
\hline Indonésia & 78.700 & 87.848 & 5,57 & Alemanha & 82.894 & 225.313 & 4,04 & Suécia & & 8.830 & 292.630 & 4,27 \\
\hline França & 76.886 & 117.534 & 5,44 & China & 76.562 & 84.056 & 3,73 & Canadá & & 8.751 & 172.466 & 3,93 \\
\hline Finlândia & 53.663 & 68.325 & 3,80 & França & 70.077 & 163.132 & 3,41 & México & 80. & .084 & 87.827 & 2,65 \\
\hline Espanha & 40.209 & 64.781 & 2,85 & Turquia & 60.384 & 79.255 & 2,94 & França & & 356 & 134.353 & 2,46 \\
\hline $\operatorname{Brazil}\left(31^{\circ}\right)$ & 10.000 & 11.494 & 0,71 & $\operatorname{Brasi}\left(44^{\circ}\right)$ & 5.000 & 8.181 & 0,24 & $\operatorname{Brasil}\left(42^{\circ}\right)$ & & 354 & 10.882 & 0,24 \\
\hline Mundo & 1.412 .623 & 2.150 .236 & 100 & Mundo & 2.052 .977 & 3.440 .179 & 100 & Mundo & 3.019 & 9.110 & 4.931 .916 & 100 \\
\hline
\end{tabular}

Fonte: baseado em FAOSTAT.

Teoria e Evidência Econômica - Ano 23, n. 48, p. 118-149, jan./jun. 2017 
Tabela 3 - Importações mundiais de papéis tissue no mundo e em países selecionados (1970 a 2014) (valores deflacionados a dólares constantes de 2014)

\begin{tabular}{|c|c|c|c|c|c|c|c|c|c|c|c|}
\hline \multicolumn{4}{|c|}{1970} & \multicolumn{4}{|c|}{1980} & \multicolumn{4}{|c|}{1990} \\
\hline Países & Quant.(t) & Valor(mil US\$) & Particip. $(\%)$ & Países & Quant.(t) & Valor(mil US\$) & Particip.(\%) & Países & Quant.(t) & Valor(mil US\$) & Particip.(\%) \\
\hline Hungria & 65.400 & 81.063 & 21,76 & Reino Unido & 76.600 & 266.536 & 18,98 & Reino Unido & 128.200 & 330.862 & 15,99 \\
\hline Itália & 48.700 & 189.111 & 16,20 & França & 57.700 & 103.716 & 14,30 & França & 121.000 & 280.840 & 15,09 \\
\hline Alemanha & 42.800 & 97.403 & 14,24 & Alemanha & 51.400 & 162.777 & 12,74 & EUA & 119.000 & 222.159 & 14,84 \\
\hline Iugoslávia & 26.000 & 22.491 & 8,65 & Japão & 46.000 & 245.068 & 11,40 & Alemana & 91.700 & 257.163 & 11,44 \\
\hline EUA & 12.000 & 25.607 & 3,99 & Holanda & 21.800 & 77.770 & 5,40 & Suíca & 75.000 & 318.331 & 9,36 \\
\hline Suécia & 10.700 & 25.052 & 3,56 & Bélgica-Luxemburgo & 20.000 & 80.821 & 4,96 & Bélgica-Luxemburgo & 58.100 & 204.885 & 7,25 \\
\hline França & 10.000 & 40.666 & 3,33 & Itália & 20.000 & 68.205 & 4,96 & Espanha & 34.800 & 97.841 & 4,34 \\
\hline Holanda & 9.600 & 21.071 & 3,19 & Canadá & 16.400 & 81.645 & 4,06 & Holanda & 27.000 & 70.134 & 3,37 \\
\hline Reino Unido & 9.600 & 58.529 & 3,19 & Dinamarca & 13.600 & 43.828 & 3,37 & Itália & 20.000 & 62.732 & 2,49 \\
\hline Malásia & 8.100 & 1.347 & 2,69 & Hungria & 10.000 & 34.827 & 2,48 & Canadá & 19.100 & 38.350 & 2,38 \\
\hline $\operatorname{Brasil}\left(19^{\circ}\right)$ & 1.900 & 12.242 & 0,63 & $\operatorname{Brasil}\left(34^{\circ}\right)$ & 700 & 7.886 & 0,17 & Brasil & $\mathrm{N} / \mathrm{D}$ & $\mathrm{N} / \mathrm{D}$ & N/D \\
\hline Mundo & 300.580 & 775.404 & 100 & Mundo & 403.600 & 1.418 .647 & 100 & Mundo & 801.700 & 2.118 .634 & 100 \\
\hline
\end{tabular}

\begin{tabular}{|c|c|c|c|c|c|c|c|c|c|c|c|}
\hline \multicolumn{4}{|c|}{2000} & \multicolumn{4}{|c|}{2010} & \multicolumn{4}{|c|}{2014} \\
\hline Países & Quant.(t) & Valor(mil US\$) & Particip.(\%) & Países & Quant.(t) & Valor(mil US\$) & Particip.(\%) & Países & Quant.(t) & Valor(mil US\$) & Particip. (\%) \\
\hline$\overline{\mathrm{EUA}}$ & 160.622 & 227.464 & 12,10 & Reino Unido & 358.966 & 283.959 & 15,58 & Alemanha & 652.000 & 1.235 .370 & 21,60 \\
\hline Reino Unido & 145.000 & 244.687 & 10,92 & EUA & 295.000 & 348.000 & 12,80 & EUA & 299.000 & 380.002 & 9,91 \\
\hline Alemanha & 143.000 & 172.725 & 10,77 & Alemanha & 199.469 & 333.235 & 8,66 & Reino Unido & 235.000 & 372.680 & 7,78 \\
\hline França & 130.612 & 180.511 & 9,84 & França & 91.772 & 153.690 & 3,98 & Austrália & 98.595 & 145.883 & 3,27 \\
\hline Espanha & 81.907 & 123.458 & 6,17 & Hungria & 74.416 & 107.728 & 3,23 & Hungria & 94.062 & 123.103 & 3,12 \\
\hline México & 70.000 & 93.765 & 5,27 & Canadá & 72.000 & 97.343 & 3,13 & Polônia & 86.694 & 146.338 & 2,87 \\
\hline Canadá & 47.617 & 66.121 & 3,59 & Austrália & 68.000 & 108.855 & 2,95 & Canadá & 82.641 & 118.791 & 2,74 \\
\hline Austrália & 42.000 & 51.417 & 3,16 & Espanha & 66.573 & 108.733 & 2,89 & França & 66.485 & 115.397 & 2,20 \\
\hline Itália & 41.000 & 72.999 & 3,09 & Irã & 60.920 & 108.855 & 2,64 & Grécia & 63.528 & 87.977 & 2,10 \\
\hline China & 31.166 & 23.381 & 2,35 & México & 60.521 & 91.895 & 2,63 & Arábia Saudita & 57.167 & 75.587 & 1,89 \\
\hline $\operatorname{Brasil}\left(35^{\circ}\right)$ & 3.400 & 8.678 & 0,26 & $\operatorname{Brasil}\left(64^{\circ}\right)$ & 4.595 & 8.678 & 0,20 & $\operatorname{Brasil}\left(66^{\circ}\right)$ & 5.782 & 14.660 & 0,19 \\
\hline Mundo & 1.327 .242 & 1.892 .513 & 100 & Mundo & 2.303 .977 & 3.466 .128 & 100 & Mundo & 3.018 .653 & 4.775 .598 & 100 \\
\hline
\end{tabular}

Fonte: baseado em FAOSTAT.

\subsection{Evolução da produção, da exportação, da importação e do consumo aparente de papéis tissue no Brasil}

A produção de papéis tissue, no Brasil, vem crescendo a ritmo mais acelerado do que a produção total de papéis no país (Figura 3). A taxa geométrica de crescimento anual (TGCA) da produção de papéis tissue ao longo de período de 1962 a 2015 foi de 7,48\%, enquanto que a TGCA da produção total de papéis foi de 5,71\%. Isso fez com que a participação da produção de papéis tissue, no total de papéis produzidos no país, passasse de 4,2\%, em 1962, para 10,8\% em 2015. Esse crescimento tornou o segmento o terceiro principal tipo de papel produzido no Brasil, atrás dos papéis de embalagens e dos de imprimir e escrever (IBÁ, 2016). 
Figura 3 - Evolução da produção total de papéis e de papéis tissue de 1962 a 2015

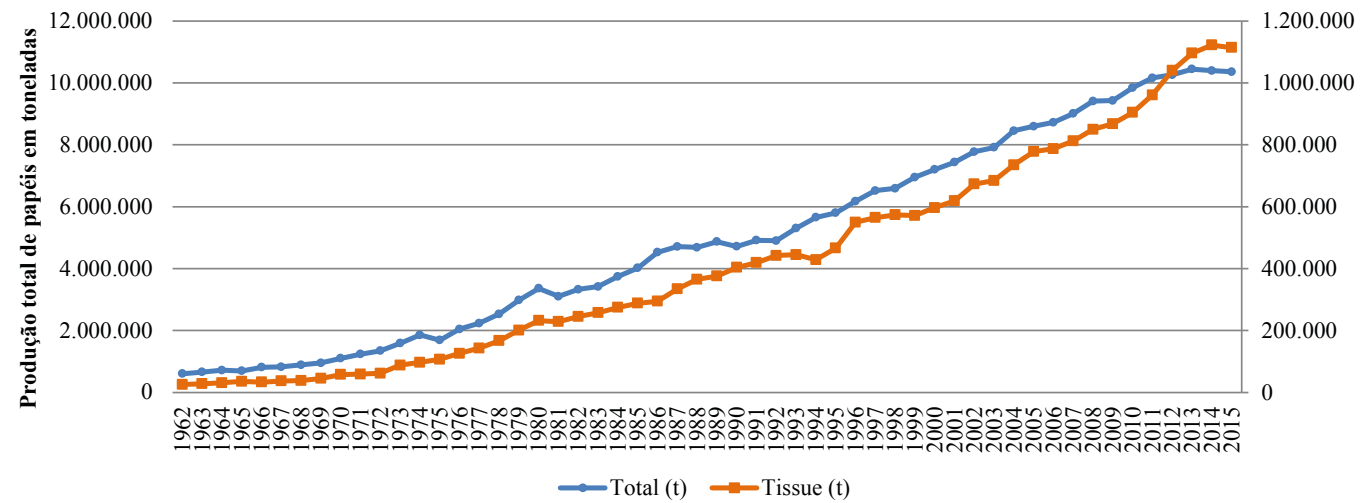

Fonte: baseado em ANFPC, Bracelpa e Ibá.

Esses resultados mostram as diferenças entre o potencial de crescimento da produção dos papéis tissue e sua demanda e a produção e a demanda pelos demais tipos de papéis. Enquanto os demais segmentos da indústria de papéis sofrem desaceleração de seu crescimento por conta do avanço tecnológico de novos produtos que substituem o consumo de papel, o segmento de papéis tissue continua crescendo no Brasil. No entanto, a crise econômica brasileira, iniciada em 2014, interrompeu a trajetória de crescimento do segmento em 2015. Observa-se, pela Figura 3, que alguns anos antes da crise, a partir de 2011, a produção total de papéis praticamente se estagnou, enquanto que a produção de papéis tissue continuou crescendo até 2014, mas arrefeceu-se em 2015.

Em relação ao comércio exterior de papéis tissue pelo Brasil, os dados mostram que, tanto as exportações, quanto as importações, não são muito significativas em relação à produção e ao consumo interno, mais uma vez reforçando a tese de que a produção de papéis tissue, voltada ao consumo interno, é preferível às vendas externas (Figura 4).

Observa-se, na Figura 4, que, com exceção dos anos de 1993 e de 1994, que aparecem como dados outliers (valor atípico, que se afasta muito dos demais valores da série), uma parcela baixa do total produzido no país é destinada a exportações. O pico nas quantidades exportadas nesses anos pode ser explicado pela drástica queda de preço dos produtos tissue, observada no período de 1990 a 1994 , que pode ter motivado os produtores a buscarem mais o mercado externo, para escoar sua produção. Na média do período de 1973 a 2015, a participação das exportações sobre o total produzido no Brasil de papel tissue foi de 4,25\%, sendo que no período mais recente, a começar em 2007, essa participação ficou abaixo dos $2 \%$. Entretanto, percebe-se um leve crescimento das exportações em 2014 e 2015, anos 
que coincidem com o início da crise econômica brasileira que reduziu a demanda por papéis tissue no país (ABTCP, 2016). A recessão interna, somada à forte desvalorização da moeda brasileira no período, tendeu a favorecer as exportações. Não tendo vendas domésticas, parte dos produtores se volta para o mercado externo.

Quanto às importações de papéis tissue, percebe-se que elas têm uma relevância ainda menor do que as exportações, tendo aquelas uma média de participação sobre o consumo aparente no país de apenas 1,03\% no período de 1990 (ano do primeiro dado de importação) a 2015.

Figura 4 - Evolução das participações nas exportações de papéis tissue sobre o total produzido e nas importações sobre o consumo aparente desse tipo de papel entre os anos de 1973 e 2015

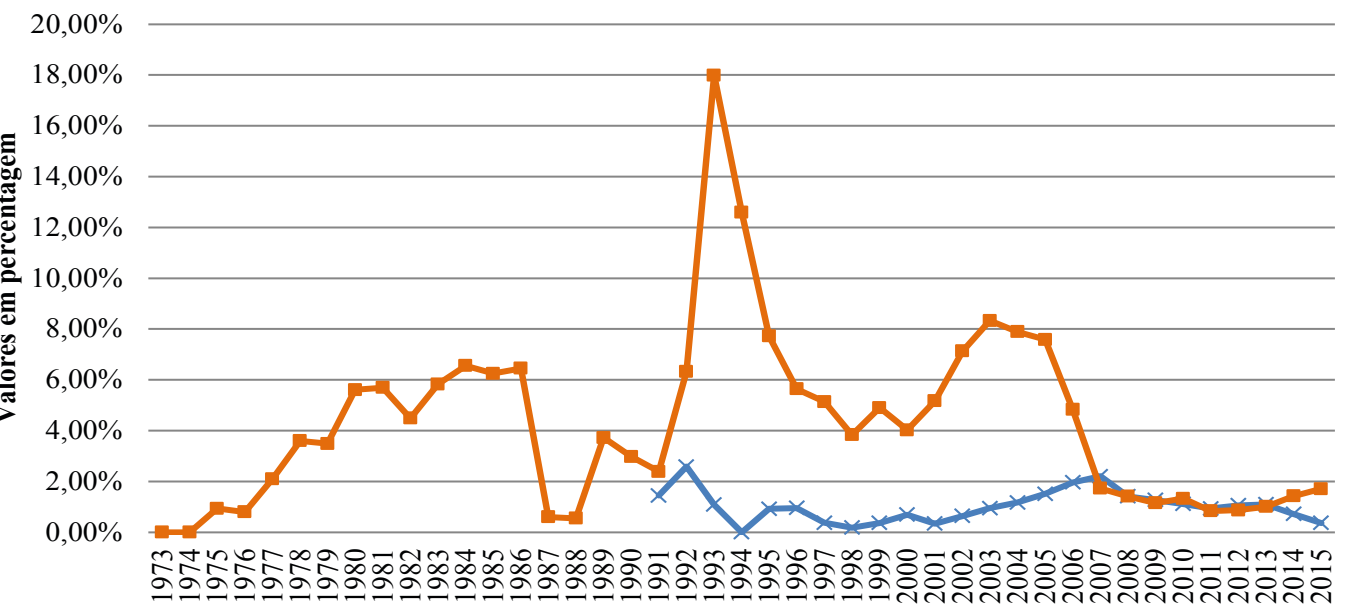

Fonte: baseado em ANFPC, Bracelpa e Ibá.

Dessa forma, infere-se que a atual estrutura do segmento produtor de papéis tissue no Brasil não influencia e nem é influenciada pelo comércio internacional, quando se considera apenas seu produto final, indicando que a concorrência externa não causa impactos relevantes no mercado interno. Entretanto, isso não significa dizer que o segmento é imune ao comércio internacional, uma vez que a celulose (principal matéria-prima para a produção de papéis tissue de melhor qualidade) é fortemente comercializada internacionalmente pelo Brasil, em que mais de 70\% da celulose produzida no país é exportada (ABTCP, 2016). Dessa forma, mudanças nos preços internacionais da celulose ou na taxa de câmbio brasileira, certamente, podem impactar o segmento brasileiro de papéis tissue.

O consumo aparente per capita de papel foi crescente durante boa parte do período de 1973 a 2015, tanto para o total de papéis, quanto para os papéis tissue 
(Figura 5). Entretanto, em 2015 houve uma queda muito acentuada no consumo aparente per capita total de papéis.

Figura 5 - Evolução do consumo aparente per capita de papel total e tissue no Brasil

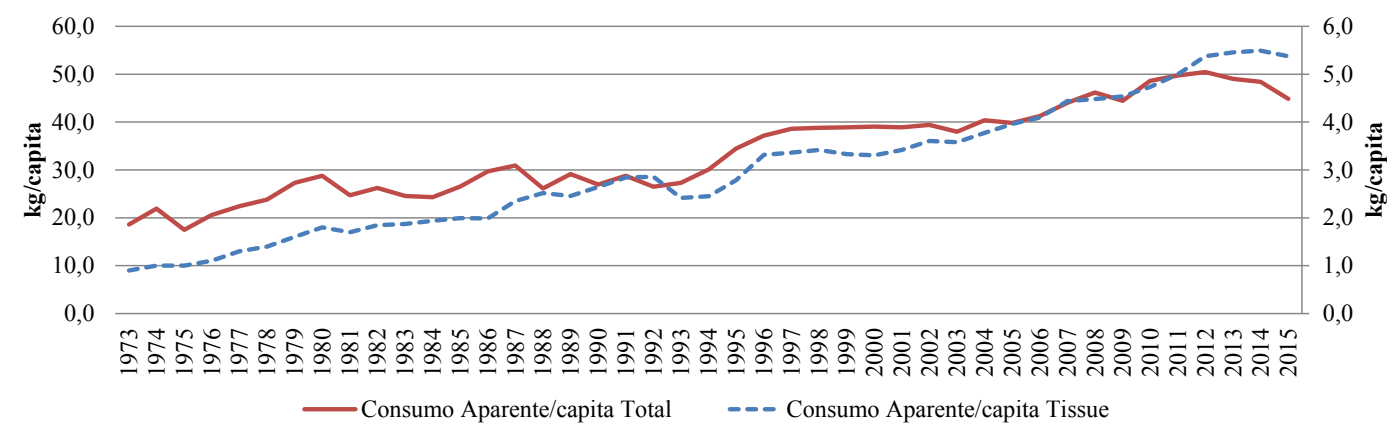

Fonte: baseado em ANFPC, Bracelpa e Ibá.

Atingindo a marca de consumo de 5,5 kg de papéis tissue por pessoa em 2014, o Brasil se igualou à média per capita de consumo mundial por papéis tissue, porém continua atrás da média de consumo de vários países mais desenvolvidos, como os Estados Unidos, o Reino Unido, a Alemanha e o Japão, que têm consumos de $13,1 \mathrm{~kg}, 10,2 \mathrm{~kg}, 8,2 \mathrm{~kg}$ e 6,4 kg por pessoa, respectivamente (@Euromonitor International). O Chile, um país geograficamente mais próximo ao Brasil, tem um consumo de $8,1 \mathrm{~kg}$ de papéis tissue por pessoa, e o consumo similar da Argentina chega a 5,6 kg por pessoa, o que é mais um indicativo de quanto o segmento ainda tem potencial de crescimento no Brasil.

\section{3 - Estrutura do segmento produtor de papéis tissue no Brasil: indicadores de concentração e de desigualdade}

A concentração da produção no segmento produtor de papéis tissue teve tendência de aumento, apesar de algumas flutuações, no período de 1985 a 2014. Observa-se, na Tabela 4, que os valores dos indicadores de concentração (CR4 e CR8) não tiveram evolução contínua, pois houve momentos de estabilidade e, até mesmo, de queda dos mesmos, apesar da tendência de alta. Os indicadores de desigualdade (HHI) também tiveram crescimento, porém, da mesma forma que os CR4 e CR8, há flutuações, com momentos de queda e outros de estabilidade. 
Tabela 4 - Indicadores de concentração e de desigualdade da distribuição da produção de papéis tissue no Brasil, em anos selecionados do período de 1985 a 2005

\begin{tabular}{c|c|c|c|c|c|c|c|c|c}
\hline \multicolumn{2}{|c|}{1985} & \multicolumn{2}{c|}{1990} & \multicolumn{2}{c|}{1995} & \multicolumn{2}{c|}{2000} & \multicolumn{2}{c}{2005} \\
\hline Empresa & $\begin{array}{c}\text { Participação na } \\
\text { produção total }\end{array}$ & Empresa & $\begin{array}{c}\text { Participação na } \\
\text { produção total }\end{array}$ & Empresa & $\begin{array}{c}\text { Participação na } \\
\text { produção total }\end{array}$ & Empresa & $\begin{array}{c}\text { Participação na } \\
\text { produção total }\end{array}$ & $\begin{array}{c}\text { Empresa } \\
\text { Participação na } \\
\text { produção total }\end{array}$ \\
\hline Klabin & $14,19 \%$ & Klabin & $13,32 \%$ & Klabin & $29,88 \%$ & Klabin Kimberly & $20,21 \%$ & Kimberly Clark* & $17,76 \%$ \\
$15,97 \%$ \\
St. Therezinha* \\
Manikraft
\end{tabular}

Fonte: baseado em ANFPC $(1985,1990,1995)$ e Bracelpa $(2000,2005)$.

Os anos de 1985 e de 1990 foram os que registraram os menores valores para os indicadores de concentração e de desigualdade no período em análise. Com CR4 abaixo de 50\% (mas cima de 35\%), o grau de concentração do segmento produtor de papéis tissue pode ser classificado em moderadamente baixo, conforme a classificação de Leite (1998), apresentada no Quadro 1. O HHI mais baixo, também indica que, nessa época, a produção foi mais igualitariamente distribuída entre os produtores (Tabela 4).

O ano de 1995 é o que apresenta os maiores valores para os indicadores de concentração e de desigualdade na distribuição da produção do segmento em análise. Isto, provavelmente, é reflexo do processo de fusões e aquisições que impactaram o setor de celulose e de papel em meados da década de 1990 (MONTEBELLO; BACHA, 2013). Em 1995, os valores do CR4 e do HHI foram, respectivamente, de $63,12 \%$ e 0,14 (Tabela 4), fazendo com que o setor passasse a ser classificado como moderadamente alto, quase chegando à classificação de alto (quanto a sua concentração). Nota-se que o principal motivo do crescimento dos indicadores CR4 e HHI foi o forte aumento da participação da empresa Klabin na produção total. Cabe ressaltar que, em 1992, a Klabin adquiriu a divisão da empresa COPA, que, em 1990, era a terceira maior produtora de papéis, comprovando que o processo de fusões e aquisições da década de 1990 aumentou a concentração da indústria de papel (MONTEBELLO; BACHA, 2013), que também teve impactos no segmento de papéis tissue.

Os valores de CR4 e HHI, em 2000, são menores do que os observados em 1995, e pouca alteração ocorreu nesses valores entre 2000 e 2005 . Nota-se que houve uma mudança na empresa líder. As empresas Klabin e Kimberly Clark formaram uma joint venture no final de 1998, criando a empresa Klabin Kimberly, indicada no ano 2000, na Tabela 4. Em 2003, essa união foi encerrada com a Kimberly Clark adquirindo 100\% do controle acionário da Klabin Kimberly, passando aquela a ser a empresa líder em 
produção no mercado e encerrando a participação da Klabin no segmento produtor de papéis tissue. Pode-se afirmar que a queda da participação da empresa líder na produção total (em 1995 detinha cerca de $30 \%$ da produção, porcentagem que caiu para $20 \%$ em 2000 e $18 \%$ em 2005) se deve muito a um crescimento da participação de empresas menores que, mesmo ainda não se classificando entre as quatro maiores produtoras, passaram a ter fatias maiores do mercado, diminuindo a desigualdade na distribuição de sua produção e fazendo com que o HHI caísse do 0,14 de 1995 para o valor de 0,09 em 2000 e 2005. A queda do CR4 não fez com que a classificação do grau de concentração do segmento saísse do moderadamente alto, porém ficou mais próximo de ser considerado moderadamente baixo do que alto (ver o Quadro 1).

Como já dito, os dados de produção por empresa das fontes citadas (ANFPC e Bracelpa) se encerraram em 2005, impossibilitando o cálculo dos indicadores de concentração e de desigualdade do segmento em análise. Porém, é possível ter uma visão um pouco mais simplificada do segmento por meio da análise dos dados disponíveis na Tabela 5 sobre as vendas por empresa de papel higiênico que, como é mostrado mais adiante no estudo, é o principal produto do segmento de papéis tissue e, portanto, sua estrutura de mercado pode dar uma aproximação razoável da estrutura do segmento como um todo. Cabe enfatizar, novamente, que, devido a diferenças metodológicas entre as fontes dos dados mostrados nas tabelas 4 e 5 , não é recomendável utilizar seus dados de forma integrada, pois os dados da Tabela 5 foram calculados com base no valor das vendas das empresas produtoras de papéis higiênicos, enquanto que os dados da Tabela 4 foram calculados com base na quantidade produzida por cada empresa produtora do segmento em análise. Logo, o ideal é analisar o período dos dados da Tabela 5 de forma isolada dos períodos anteriores.

Apesar da já mencionada diferença entre os tipos de dados, os apresentados na Tabela 5 indicam as mesmas quatro empresas líderes do ano de 2005 da Tabela 4 e também indicam um valor de CR4 muito próximo do apresentado anteriormente.

Tabela 5 - Indicadores de concentração de vendas de papel higiênico de 2005 a 2014 (valores em \%)

\begin{tabular}{ccccccccccc}
\hline Empresas & 2005 & 2006 & 2007 & 2008 & 2009 & 2010 & 2011 & 2012 & 2013 & 2014 \\
\hline Santher & 20,0 & 19,5 & 17,5 & 17,4 & 19,6 & 21,3 & 23,4 & 23,9 & 24,3 & 24,9 \\
Kimberly Clark & 18,2 & 13,0 & 13,4 & 13,7 & 13,8 & 13,6 & 11,2 & 12,7 & 13,0 & 15,8 \\
Mili SA & 6,1 & 5,8 & 5,6 & 5,3 & 6,0 & 7,6 & 9,1 & 10,8 & 11,5 & 13,6 \\
Empresas CMPC SA & - & - & - & 6,2 & 6,9 & 7,3 & 7,7 & 7,8 & 7,6 & 7,6 \\
Sepac & - & 4,1 & 3,8 & 4,0 & 4,3 & 4,4 & 4,7 & 4,6 & 4,6 & 5,4 \\
Manikraft & 3,3 & 2,9 & 2,4 & 2,6 & 2,8 & 3,0 & 3,3 & 3,8 & 3,7 & 4,0 \\
Volta Grande & 1,9 & 1,6 & 1,2 & 1,1 & 1,1 & 1,2 & 1,2 & 1,1 & 1,2 & 0,9 \\
Melhoramentos & 9,3 & 8,7 & 7,7 & - & - & - & - & - & - & - \\
Outras & 46,4 & 53,0 & 55,8 & 57,4 & 53,7 & 50,2 & 48,7 & 44,8 & 43,6 & 36,6 \\
\hline CR4 & $\mathbf{5 3 , 5 8}$ & $\mathbf{4 7 , 0 2}$ & $\mathbf{4 4 , 1 6}$ & $\mathbf{4 2 , 5 8}$ & $\mathbf{4 6 , 2 8}$ & $\mathbf{4 9 , 7 8}$ & $\mathbf{5 1 , 3 5}$ & $\mathbf{5 5 , 1 9}$ & $\mathbf{5 6 , 4 1}$ & $\mathbf{6 3 , 4 0}$ \\
\hline
\end{tabular}

Fonte: baseado em @Euromonitor International. 
Pelos dados da Tabela 5, observa-se uma redução no CR4 do segmento produtor de papéis tissue, ficando esse indicador abaixo dos 50\% (mas acima de 35\%) entre os anos de 2006 e 2010, fazendo seu grau de concentração cair para moderadamente baixo como reflexo do aumento da participação de empresas menores (agregadas na categoria Outras), sendo a Kimberly Clark a empresa entre as líderes que mais perdeu espaço.

Todavia, a partir de 2009 a concentração do segmento passou a aumentar com as empresas líderes retomando o espaço perdido, com destaque para o grande crescimento das empresas Mili S.A. e da Kimberly Clark. Esse aumento do CR4 fez com que, a partir de 2011, o segmento voltasse ao grau de concentração moderadamente alto, encerrando o ano de 2014 próximo da classificação de nível alto.

Outros trabalhos também calcularam indicadores de concentração do segmento produtor de papéis tissue, como o de Carrazza e Bacha (2004) e o de Montebello e Bacha (2013). Apesar de os dados utilizados nos três trabalhos serem da mesma fonte, observa-se uma divergência entre os resultados deles, principalmente em relação ao de Montebello e Bacha (2013), que apresenta indicadores de concentração consideravelmente menores do que os de Carrazza e Bacha (2004) e dos obtidos neste estudo (compare-se os dados das tabelas 6 e 7 com os dados da Tabela 4).

Essa diferença pode estar na forma com que os autores agregaram os dados de cada empresa em grupos. Para o cálculo dos indicadores, o presente artigo teve o cuidado de, a cada ano, agregar a produção de unidades produtoras diferentes, porém pertencentes a uma mesma empresa, fazendo com que empresas que detêm mais de uma unidade produtora ficassem com uma participação maior na produção, tornando os indicadores de concentração e de desigualdade do segmento maiores do que se considerasse cada unidade produtora como uma única empresa individualmente.

Tabela 6 - Indicadores de concentração e de desigualdade da distribuição da produção de papéis tissue no Brasil, nos anos de 1982, 1990, 2000 e 2009 (valores de CR4 em \%)

\begin{tabular}{c|c|c|c|c}
\hline Ano & Produção (em toneladas) & Número de empresas & CR4 & HHI \\
\hline 1982 & 245.032 & 27 & 38,2 & 0,06 \\
1990 & 403.712 & 44 & 28,8 & 0,04 \\
2000 & 596.732 & 43 & 33,4 & 0,05 \\
2009 & 867.912 & 39 & 39,3 & 0,06 \\
\hline
\end{tabular}

Fonte: Montebello e Bacha (2013), baseados em ANFPC e Bracelpa.

Tabela 7 - Indicadores de concentração de produção de papéis tissue anos de 1982, 1992 e 2002

\begin{tabular}{c|c|c|c}
\hline Ano & Produção (em toneladas) & Número de empresas & CR4 \\
\hline 1982 & 245.032 & 31 & 41,40 \\
1992 & 442.382 & 45 & 42,00 \\
2002 & 673.117 & 27 & 49,20 \\
\hline
\end{tabular}

Fonte: Carrazza e Bacha (2004), baseados em ANFPC e Bracelpa. 


\subsection{Estrutura do segmento produtor de papéis tissue no Brasil: distribuição geográfica da produção}

Historicamente, a produção de papéis tissue no Brasil se concentra nas regiões Sul e Sudeste, com uma constante liderança do estado de São Paulo sobre os demais estados. Entretanto, essa participação do estado de São Paulo no total produzido caiu no período de 1985 a 2008 (Tabela 8). A maior concentração da produção de papéis tissue no Brasil em áreas mais povoadas e, portanto, de maior mercado consumidor, é mais um reflexo das características físicas dos diferentes tipos de papéis tissue, reforçando a tese de que sua produção deve ser mais voltada para o consumo em áreas próximas de sua fabricação por conta dos custos relativamente altos de seus transportes.

A tendência de queda da participação do estado de São Paulo na produção total de papéis tissue no país se deve principalmente a um grande crescimento da produção das empresas catarinenses, como a Mili S.A. - empresa que, em 2005, pela primeira vez, se classificou entre as quatro principais empresas produtoras (ver Tabela 4) e tem uma tendência de aumentar ainda mais sua participação (ver Tabela 5) -, e a estratégia de migração da produção por parte de outras empresas líderes, como a Kimberly Clark (antiga Klabin e Klabin Kimberly), do estado de São Paulo para o de Santa Catarina. Outro estado que também perdeu participação na produção nacional de papéis tissue ao longo dos anos foi o Rio de Janeiro, que teve sua principal empresa, a COPA, adquirida pela Klabin em 1992, que foi fechada no final da década de 1990, o que fez reduzir drasticamente a participação fluminense na produção nacional de papéis tissue. Somado a isso, as pequenas empresas produtoras do estado do Rio de Janeiro não conseguiram manter seus níveis de produção. 
Tabela 8 - Distribuição geográfica da produção de papéis tissue entre estados brasileiros produtores de 1985 a 2008

\begin{tabular}{c|c|c|c|c|c|c}
\hline Estado/Anos & 1985 & 1990 & 1995 & 2000 & 2005 & 2008 \\
\hline São Paulo & $63,99 \%$ & $57,66 \%$ & $49,27 \%$ & $46,53 \%$ & $43,84 \%$ & $40,10 \%$ \\
Santa Catarina & $9,08 \%$ & $4,22 \%$ & $17,41 \%$ & $20,56 \%$ & $22,59 \%$ & $26,43 \%$ \\
Paraná & $1,87 \%$ & $9,04 \%$ & $8,88 \%$ & $5,85 \%$ & $6,80 \%$ & $6,74 \%$ \\
Rio de Janeiro & $11,49 \%$ & $11,92 \%$ & $9,73 \%$ & $5,29 \%$ & $5,36 \%$ & $6,23 \%$ \\
Rio Grande do Sul & $3,29 \%$ & $4,29 \%$ & $3,96 \%$ & $4,59 \%$ & $4,89 \%$ & $4,89 \%$ \\
Minas Gerais & $4,77 \%$ & $4,90 \%$ & $5,66 \%$ & $6,55 \%$ & $4,11 \%$ & $4,82 \%$ \\
Pará & $1,71 \%$ & $1,90 \%$ & - & $2,01 \%$ & $3,54 \%$ & - \\
Bahia & $2,97 \%$ & $2,08 \%$ & $2,33 \%$ & $2,94 \%$ & $1,80 \%$ & - \\
Goiás & - & $2,40 \%$ & $1,73 \%$ & $2,07 \%$ & $1,30 \%$ & - \\
Pernambuco & - & $0,36 \%$ & $0,00 \%$ & $0,92 \%$ & $1,20 \%$ & $1,82 \%$ \\
Ceará & - & - & $0,00 \%$ & $0,27 \%$ & $1,09 \%$ & - \\
Paraíba & $0,83 \%$ & $0,98 \%$ & $1,04 \%$ & $1,00 \%$ & $1,05 \%$ & - \\
Amazonas & - & - & - & $1,12 \%$ & $0,96 \%$ & - \\
Sergipe & - & - & - & - & $0,77 \%$ & - \\
Maranhão & - & - & - & $0,30 \%$ & $0,71 \%$ & - \\
Outros* & - & - & - & - & - & $8,96 \%$ \\
Rio Grande do Norte & - & $0,25 \%$ & - & - & - & - \\
\hline
\end{tabular}

*Outros: AM, CE, GO, MA, PA, PB e SE (sanados).

Fonte: baseado em ANFPC $(1985,1990,1995)$ e Bracelpa $(2000,2005,2008)$.

\subsection{Distribuição da produção de papéis tissue por tipo e evolução de seu consumo}

O segmento produtor de papéis tissue divide sua produção em cinco tipos de produtos e alguns deles possuem categorias distintas. Têm-se, segundo definições da Bracelpa (2011): produto 1 - papel higiênico (que se divide em quatro categorias: papel higiênico popular, papel higiênico de folha simples de boa qualidade, papel higiênico de folha simples de alta qualidade e papel higiênico de folha dupla de alta qualidade); produto 2 - papel toalha (que se divide em duas categorias: papel toalha de mão e papel toalha de cozinha); produto 3 - guardanapo; produto 4 - lenço; e produto 5 - lençol hospitalar.

Em 2011 (ano do último dado da Bracelpa sobre produção por tipos de papéis tissue), a produção de papel higiênico (somando todas suas quatro categorias) correspondia a 73,25\% do total produzido de papéis tissue no país (Figuras 6 e 7), sendo que, no período de 1981 a 2011, sua participação média foi de 78,23\%. 
Figura 6 - Evolução da produção de papel higiênico por categorias entre 1981 e 2011

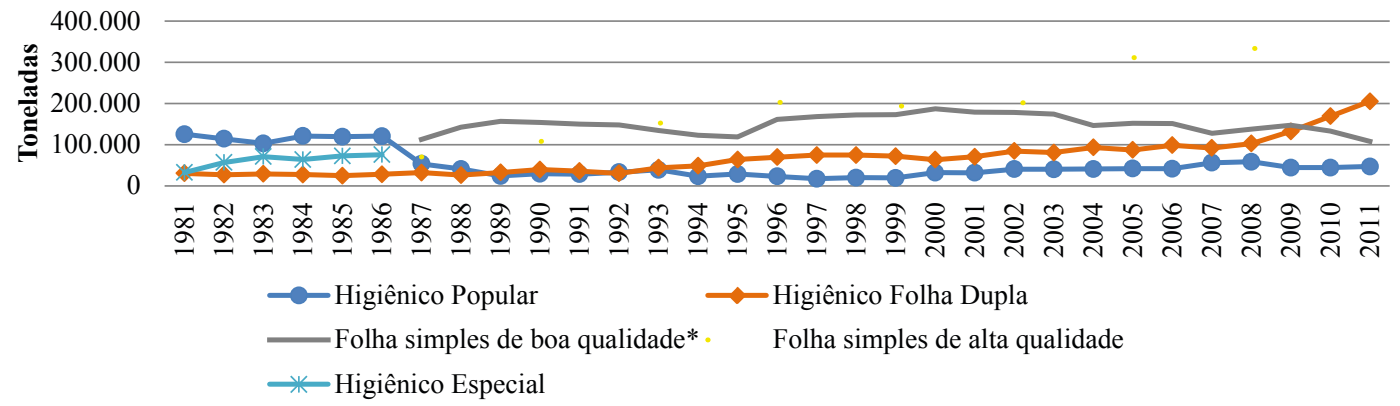

* A partir de 1987, a definição de papel higiênico especial foi substituída por folha simples de boa e alta qualidade. Essas novas definições, contudo, contêm parte da produção de papéis classificados como higiênico popular.

Fonte: baseado em ANFPC e Bracelpa.

Figura 7 - Distribuição da produção de papéis tissue por tipos de produtos, com exceção do papel higiênico, no período de 1981 a 2011

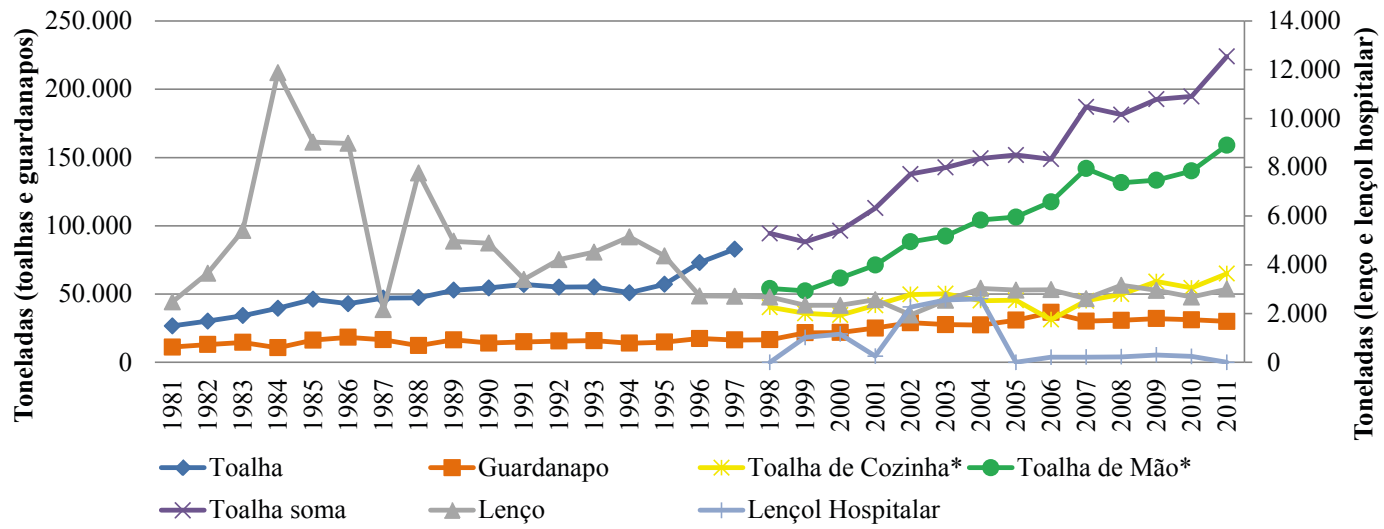

* A partir de 1998, o papel toalha foi separado em toalha de cozinha e de mão.

Fonte: baseado em ANFPC e Bracelpa.

A análise dos dados da Figura 6 permite observar como a produção de papéis tissue, seguindo as mudanças no padrão de consumo, mudou a distribuição dos tipos de produtos elaborados, passando a fabricar papéis higiênicos de maior qualidade. Em 1993, já se produzia mais papéis higiênicos de folha simples de alta qualidade do que os de boa qualidade e, em 2010, a produção de papel higiênico de folha dupla também ultrapassou a produção dos de folha simples de boa qualidade. Enquanto isso, os papéis higiênicos populares, de pior qualidade, vêm perdendo 
cada vez mais espaço por ter sua produção estabilizada, enquanto as produções de itens de alta qualidade crescem.

Mais recentemente, passou a ser comercializado papel higiênico de folha tripla e papel higiênico umedecido (ABTCP, 2015), produtos de valor agregado ainda maior, entretanto, não há dados disponíveis de produção dessas categorias para serem analisados neste artigo.

A mudança no padrão de consumo da população brasileira é consequência direta do aumento do seu poder aquisitivo, que tende a aumentar a procura por produtos de melhor qualidade. Uma melhor distribuição de rendimentos e a diminuição da população em extrema miséria também aumentam o acesso de mais pessoas ao mercado consumidor.

Outra consequência do aumento da renda da população brasileira no segmento de papéis tissue é observada no aumento da produção de papéis toalha de mão e de cozinha. O primeiro é geralmente usado na categoria away from home (fora de casa), normalmente em hotéis e restaurantes que têm espaço de higiene pessoal para seus clientes ou funcionários. Em uma economia dinâmica e em crescimento, que leva ao surgimento de novos empreendimentos no setor industrial e, principalmente, no setor de serviços, tende a aumentar a demanda e a produção dos papéis tissue do tipo toalha de mão.

A produção de papel toalha de cozinha, apesar de ter uma participação mais tímida do que os produtos já citados, também não deixa de sofrer os impactos dos aumentos da renda da população. Esse produto geralmente é usado para limpeza doméstica, e os aumentos da sua produção e consumo também são consequências do aumento do poder aquisitivo da população, que passa a substituir o pano de limpeza reutilizável pelo papel toalha descartável.

\subsection{Estimação das funções de demanda de papéis tissue no Brasil}

A Tabela 9 apresenta os dados utilizados nas regressões sugeridas no Quadro 2. Os resultados ex ante esperados dos modelos elaborados eram de se obter valores negativos de $\alpha_{1}$ e positivos de $\alpha_{2}$ (ver quadro 2 do item 4.1), o que indicaria uma relação inversa entre preço e consumo (o esperado em função de demanda) e uma relação direta entre a renda e o consumo, para confirmar a tese de que o aumento da renda do brasileiro leva-o a consumir mais os diferentes tipos de papéis tissue. 
Tabela 9 - Dados utilizados nas regressões de demanda por papéis tissue

\begin{tabular}{c|c|c|c}
\hline Ano & $\begin{array}{c}\text { Consumo } \\
\text { aparente (t) }\end{array}$ & $\begin{array}{c}\text { Preço médio } \\
(\text { R } \$ \text { t)* }\end{array}$ & $\begin{array}{c}\text { PIB Brasil } \\
\text { (Bilhões de R\$)* }\end{array}$ \\
\hline 1980 & 218993 & 12193,64 & 2590,27 \\
1981 & 215497 & 11144,84 & 2480,18 \\
1982 & 234032 & 9153,47 & 2500,77 \\
1983 & 242230 & 6777,46 & 2427,50 \\
1984 & 256469 & 6343,09 & 2558,58 \\
1985 & 270218 & 8219,45 & 2759,43 \\
1986 & 275402 & 13063,30 & 2966,11 \\
1987 & 332113 & 8285,18 & 3070,81 \\
1988 & 363223 & 4263,99 & 3068,97 \\
1989 & 361870 & 1443,40 & 3165,95 \\
1990 & 397712 & 3424,33 & 3028,23 \\
1991 & 415257 & 2301,50 & 3059,47 \\
1992 & 425382 & 3054,13 & 3042,84 \\
1993 & 368694 & 1665,63 & 3192,69 \\
1994 & 374844 & 2758,85 & 3379,55 \\
1995 & 434177 & 4795,96 & 3522,19 \\
1996 & 523696 & 5220,97 & 3599,99 \\
1997 & 537713 & 5065,17 & 3722,21 \\
1998 & 552599 & 4861,96 & 3734,79 \\
1999 & 545331 & 8576,42 & 3752,27 \\
2000 & 576732 & 4813,28 & 3916,92 \\
2001 & 589012 & 5084,64 & 3971,36 \\
2002 & 629117 & 6356,73 & 4092,62 \\
2003 & 633160 & 4666,51 & 4139,31 \\
2004 & 685049 & 4050,13 & 4377,73 \\
2005 & 729933 & 3926,78 & 4517,91 \\
2006 & 764417 & 3616,58 & 4696,91 \\
2007 & 816305 & 3249,07 & 4982,01 \\
2008 & 849739 & 3859,31 & 5235,80 \\
2009 & 868912 & 3876,60 & 5229,22 \\
2010 & 902641 & 3650,15 & 5622,88 \\
2011 & 962000 & 3735,90 & 5842,69 \\
2012 & 1042000 & 4024,32 & 5954,75 \\
2013 & 1097000 & 3906,37 & 6134,21 \\
2014 & 1114000 & 3855,04 & 6140,60 \\
2015 & 1099000 & 4929,75 & 5904,33 \\
\hline
\end{tabular}

*Valores em reais constantes de 2015.

Fontes: ANFPC (1980-1996), Bracelpa (1996-2011), Ibá (2012-2015), FAO (2016), Bacen (2016).

Considerando essas expectativas, o modelo que apresentou os resultados mais satisfatórios foi o primeiro modelo, estimado com as variáveis transformadas em logaritmo. Nesse modelo, ambos os parâmetros estimados $\left(\alpha_{1}\right.$ e $\left.\alpha_{2}\right)$ foram estatisticamente significativos a $5 \%$ e tiveram os sinais esperados (ver Tabela 10). Entretanto, realizando os testes para detectar heterocedasticia e autocorrelação dos resíduos, detectou-se que os resultados mostraram presença de autocorrelação dos resíduos da regressão, e a hipótese nula de homocedasticia foi rejeitada ao nível de significância de $10 \%$. Como a regressão foi feita com valores em logaritmo, não é possível corrigir a autocorrelação, aplicando a diferença nos dados. Para correção da heterocedasticia foi realizada a correção robusta 
de White. O valor de $-0,076$ (segunda regressão da Tabela 10), estimado para o parâmetro $\alpha_{1}$, é estatisticamente significativo a $10 \%$ e indica que a demanda por papéis tissue é inelástica em relação ao seu preço (no caso da regressão feita em logaritmos, o valor dos parâmetros estimados é igual aos das elasticidades), ou seja, o consumo desses produtos não é muito sensível à variação de preços. O valor de 1,671 (segunda regressão da Tabela 10), estimado para o parâmetro $\alpha_{2}$, é estatisticamente significativo a $0,01 \%$ e indica que os produtos de papéis tissue se comportam como bens de luxo, ou seja, um determinado aumento de renda dos consumidores gera, proporcionalmente, um aumento ainda maior no consumo desse tipo de bem.

Tabela 10 - Resultados da regressão e da estimação dos parâmetros para função de demanda de papéis tissue no Brasil

\begin{tabular}{|c|c|c|c|c|c|c|c|c|}
\hline \multicolumn{2}{|l|}{ Modelo 1} & Constante & Preço & Renda & $\mathrm{R}^{2}$ & Teste F & Teste de & Teste de \\
\hline \multirow{4}{*}{ Dados em logaritmo } & \multirow{2}{*}{ Coeficiente } & \multirow{2}{*}{0,016} & \multirow{2}{*}{$-0,076$} & \multirow{2}{*}{1,671} & \multirow[t]{4}{*}{0,970} & 541,219 & \multirow[t]{4}{*}{0,931} & chi2 \\
\hline & & & & & & Prob $(F)$ & & 12,84 \\
\hline & Estatística t & 0,025 & $-2,327$ & 29,802 & & 0,000 & & Prob $>$ chi2 \\
\hline & Probabilidade & 0,980 & 0,026 & 0,000 & & & & 0,0250 \\
\hline \multirow{4}{*}{$\begin{array}{c}\text { Dados em logaritmo } \\
\text { (correção robusta de White) }\end{array}$} & Confionto & 0016 & 0076 & 1671 & \multirow[t]{4}{*}{0,970} & 785,080 & \multirow[t]{4}{*}{0,931} & \\
\hline & Coentiente & 0,010 & $-0,0 / 0$ & $1,0 / 1$ & & Prob $(F)$ & & \\
\hline & Estatística t & 0,020 & $-1,690$ & 30,950 & & 0,000 & & \\
\hline & Probabilidade & 0,983 & 0,100 & 0,000 & & & & \\
\hline
\end{tabular}

Fonte: resultados da pesquisa.

As demais regressões realizadas (ver anexo) não apresentam resultados com níveis de significância aceitáveis para os coeficientes associados à variável preço. Não obstante, essas regressões apresentam, de modo geral, os sinais esperados para os coeficientes associados às variáveis preço, renda, tendência e consumo defasado.

\section{Conclusões}

O segmento produtor de papéis tissue no Brasil possui uma boa tendência de crescimento na sua produção, a qual se elevou à taxa geométrica anual de $7,48 \%$ de 1962 a 2015, maior do que a de toda a indústria de papéis (que foi de 5,71\% a.a.). Consequentemente, a importância dos papéis tissue na produção total de papéis passou de 4,2\%, em 1962, para 10,8\% em 2015. 
Há ainda boas perspectivas do crescimento da produção de papéis tissue no Brasil. Os dados de consumo per capita de países desenvolvidos indicam que ainda há muito espaço para o aumento do consumo de produtos tissue, conforme a população aumente sua renda e mais pessoas tenham acesso ao mercado consumidor de produtos de melhor qualidade.

É preciso dar atenção a como a produção atual de papéis tissue se distribui entre suas empresas produtoras, pois, apesar dos indicadores de concentração não estarem ainda em níveis alarmantes, eles tendem a subir, o que gera preocupações de exercício de poder de mercado por parte das empresas líderes, diminuindo a eficiência de bem-estar no mercado.

O fato de o comércio exterior não impactar na concorrência interna do mercado de papéis tissue, devido ao baixo nível de importações, é mais um facilitador do exercício de poder do mercado por parte das grandes empresas produtoras, caso a concentração do segmento continue a aumentar.

A mudança no padrão de consumo da população brasileira indica como períodos de crescimento da renda e de diminuição da pobreza, naturalmente, fazem com que o consumo migre dos produtos de pior qualidade para os de melhor qualidade e de maior valor agregado.

As perspectivas a médio e longo prazos para o segmento produtor de papéis tissue no Brasil são boas, pois ainda há espaço para o crescimento no consumo doméstico, principalmente dos produtos de maior qualidade. Além disso, novos produtos de qualidade superior continuam a ser lançados. Isso é um sinal de que ainda existem inovações por vir. Entretanto, é preciso que a economia esteja gerando renda crescente para que as pessoas estejam dispostas a procurar por esses novos produtos de melhor qualidade, por eles serem de fácil substituição pelos de pior qualidade.

Os resultados das regressões para estimação de uma função demanda doméstica por papéis tissue indicam que o consumo desse tipo papel é inelástico em relação ao seu preço e que se comporta como o consumo de um bem de luxo. A elasticidade-preço da demanda no valor de -0,076 dos papéis tissue indica que o consumo desse tipo de papel não é muito sensível a variações de preço. A elasticidade-renda da demanda no valor de 1,671 indica que o consumo de papéis tissue se comporta como um bem de luxo, ou seja, o aumento real na renda dos consumidores de $1 \%$ gera um aumento de $1,67 \%$ no consumo desse tipo de papel.

Este estudo procurou desenvolver uma análise mais detalhada do segmento produtor de papéis tissue no Brasil do que os trabalhos já realizados sobre os demais segmentos da indústria de papel no país, porém, ainda existem diversos outros pontos que ficam como sugestão para serem estudados em trabalhos posteriores, como análises dos aspectos de conduta e de desempenho das empresas do segmento em questão, já que o presente trabalho se ateve à análise apenas da sua estrutura e das condições básicas de demanda. 


\title{
Analysis of productive structure and consumption of tissue papers in Brazil
}

\begin{abstract}
This paper aims to analyze the structure of the tissue paper production in Brazil, especially its concentration, and the evolution of its production and consumption. Time period from 1962 through 2015 , specially years starting in 1980 , is taken into consideration. Based on the structure-conductperformance paradigm, the issues to be analyzed are: its production structure and demand conditions. Based on data collected from producer associations and Euromonitor, indicators of concentration of production (such as CR4, CR8 and HHI) were calculated as well as demand equations were run. Among the findings, we have: (1) from 1962 to 2015, the Brazilian production of tissue paper grew up at an annually geometric rate of $7.48 \%$, compared to a growth of $5.71 \%$ per year for the total paper production. Consequently, the share of tissue papers into the total Brazilian paper production grew up from $4.2 \%$ in 1962 to $10.8 \%$ in 2015. (2) Due to its higher volume and lower weight, foreign trade of tissue paper is tiny, guaranteeing market power for the companies here installed in the pricing of their products. (3) There is a regional concentration in the production of tissue paper, but it has reduced over time. (4) The demand for this product is inelastic at price changes, however it is elastic for income alterations. The price and income elasticities estimated for the period from 1980 to 2015 were -0.076 and 1.671 , respectively, showing that despite being a luxury product, the demand for tissue paper is not very sensitive to price variations.
\end{abstract}

Keywords: Demand. Demand equation. Tissue papers. Production.

\section{Análisis de la estructura productiva y del consumo de papel tisú en Brasil}

\section{Resumen}

Este artículo científico pretende analizar la estructura de la producción de papel tisú en Brasil, especialmente su concentración, y la evolución de su producción y consumo. Se toma en consideración el período de 1962 hasta 2015, especialmente los años a partir de 1980. Sobre la base del paradigma estructura-conducta-desempeño, los aspectos a examinar son: su estructura de producción y las condiciones de demanda. Con base en los datos recolectados de las asociaciones de productores y Euromonitor, se calcularon los indicadores de concentración de la producción (como CR4, CR8 y HHI) así como las ecuaciones de demanda fueran estimadas. Entre los hallazgos encontramos: (1) de 1962 hasta 2015, la producción brasileña de papel tisú creció a una tasa geométrica anual de 7,48\%, comparado con un crecimiento de 5,71\% anual para la producción total de papel. En consecuencia, la proporción de papel tisú en la producción total brasileña de papel creció de 4,2\% en 1962 a 10,8\% en 2015. (2) Debido a su mayor volumen y menor peso, el comercio exterior de papel tisú es pequeño, garantizando el poder de mercado para las empresas aquí instaladas en la fijación de precios de sus productos. (3) Hay una concentración regional en la producción de papel tisú, pero ella se ha reducido con el tiempo. (4) La demanda de este producto es inelástica a precio, pero ella es elástica para alteraciones de los ingresos. Las elasticidades de precios y de ingresos estimadas para el período de 1980 hasta 2015 fueron $-0,076$ y 1,671 , respectivamente, lo que muestra que a pesar de ser un producto de lujo, la demanda de papel tisú no es muy sensible a las variaciones de precios.

Palabras clave: Demanda. Ecuación de la demanda. Papel tisú. Producción.

Teoria e Evidência Econômica - Ano 23, n. 48, p. 118-149, jan./jun. 2017 


\section{Referências}

ABTCP - ASSOCIAÇÃO BRASILEIRA TÉCNICA DE CELULOSE E PAPEL. Coluna Indicadores de papéis tissue. BOAS, Pedro V. Revista O Papel, ago. 2015/jan. 2016.

ANFPC - ASSOCIAÇÃO NACIONAL DOS FABRICANTES DE PAPEL E CELULOSE. Relatórios estatísticos anuais de 1982 a 1996. São Paulo, vários números.

ARANHA, C. B.; BACHA, C. J. C. Evolução e estrutura da subcadeia de papéis de imprimir e escrever no Brasil. In: CONGRESSO DA SOCIEDADE BRASILEIRA DE ECONOMIA, ADMINISTRAÇÃO E SOCIOLOGIA RURAL, 49., 2011, Belo Horizonte. Brasília: SOBER, 2011. p. 1-20.

BACEN. Banco Central do Brasil. Indicadores econômicos consolidados. Disponível em: <http:// www.bcb.gov.br/pec/indeco/port/indeco.asp>. Acesso em: 20 dez. 2016.

BRACELPA. Relatórios estatísticos anuais de 1998 a 2013.

CABRINI, E. M.; BACHA, C. J. C. Análise do segmento de papéis para embalagens dentro da cadeia produtiva do papel. In: CONGRESSO DA SOCIEDADE BRASILEIRA DE ECONOMIA, ADMINISTRAÇÃO E SOCIOLOGIA RURAL, 49., 2011, Belo Horizonte. Brasília: SOBER, 2011. p. $1-20$.

CARLTON, D. W.; PERLOF, J. M. Modern Industrial Organization. 4. ed. Boston: Pearson/Addison Wesley, 2005.

CARRAZZA, L. C.; BACHA, C. J. C. Evolução e estrutura da indústria de papéis no Brasil: período de 1965 a 2002. In: CONGRESSO DA SOCIEDADE BRASILEIRA DE ECONOMIA E SOCIOLOGIA RURAL, 42., 2004, Cuiabá. Anais... Cuiabá: Sober, 2004. p. 1-14.

DAURA, S. P. Análise do setor de celulose e papel na era da globalização: um olhar sobre sua produção e mão-de-obra. 2004. 226 f. Tese (Doutorado em Ciências Sociais) - Universidade Estadual de Campinas, Campinas, 2004.

FAO - FOOD AND AGRICULTURE ORGANIZATION OF THE UNITED NATIONS. Estatisticas. Roma. Disponível em: < http://www.fao.org/forestry/46203/en/>. Acesso em: 20 dez. 2016.

FAOSTAT. Base de daos estatísticos da FAO. Disponível em: <http://www.fao.org/statistics/en/>. Acesso em: 20 dez. 2016.

IBÁ - INDÚSTRIA BRASILEIRA DE ÁRVORES. Dados e estatísticas de cenários Ibá. São Paulo. Disponível em: <http://iba.org/pt/>. Acesso em: $15 \mathrm{dez} .2016$.

ILO - INTERNATIONAL LABOUR ORGANIZATION. Globalization and sustainability: the forestry and wood industries on the move. Geneva, abr. 2001, p. 1-122. Disponível em: <http://www. ilo.org/public/libdoc/ilo/2001/101B09_179_engl.pdf>. Acesso em: 23 jan. 2017.

LEITE, A. L. S. Concentração e desempenho competitivo no complexo industrial de papel e celulose. 1998. 99 f. Dissertação (Mestrado em Engenharia de produção)-Universidade Federal de Santa Catarina, Florianópolis, 1998.

MANFIO, L. L. Evolução e estrutura da subcadeia dos papéis da linha marrom no Brasil. 2015. 56 f. Monografia (Bacharel em Ciências Econômicas) - Escola Superior de Agricultura Luiz de Queiroz, Universidade de São Paulo, Piracicaba, 2015.

MACEDO, A. R. P.; LEITE, E. T. Produtos florestais. In: . Papéis para fins sanitários. Local de publicação: BNDES, mar. 1997. p. 43-53. Disponível em: <https://web.bndes.gov.br/bib/ 
jspui/bitstream/1408/3668/3/BS\%2005\%20Papeis\%20para\%20fins\%20sanitarios_P.pdf>. Acesso em: 23 jan. 2017.

MATTOS, R. L. G.; VALENÇA, A. C. V. A reestruturação do setor de papel e celulose. BNDES Setorial, Rio de Janeiro, n. 10, p. 253-268, set. 1999.

MONTEBELLO, A. E. S.; BACHA, C. J. C. O setor de celulose e papel na economia brasileira Revista O Papel, São Paulo, v. 72, n. 4, p. 47-50, abr. 2011.

Evolução e estrutura diferenciadas dos segmentos da indústria de papéis no Brasil de 1980 a 2010. Teoria e Evidência Econômica, Passo Fundo, a. 21, n. 44, p. 96-125, jun. 2015.

Impactos da Reestruturação do Setor de Celulose e Papel no Brasil sobre o Desempenho de suas Indústrias. Est. Econ., São Paulo, v. 43, p. 109-137, mar. 2013.

OUCHI, H. C. Práticas de sustentabilidade corporativa no Brasil. 2006. 87 f. Tese (Mestrado em Administração) - Universidade Federal do Rio de Janeiro, Rio de Janeiro, 2006.

RISI. Who's who in the global tissue parent roll business? 15 abr. 2015. Disponível em: <http:// technology.risiinfo.com/tissue/global/projects/whos-who-global-tissue-parent-roll-business $>$. Acesso em: 5 dez. 2016.

SANDE, J. B. Restructuring and globalization of the forest industry: a review of trends, strategies and theories. World Forest Institute, Bergen, 24 p., mar. 2002. Disponível em: <http://www. unece.lsu.edu/marketing/documents/2003-2006/gme03_044.pdf>. Acesso em: 23 jan. 2017.

SILVA, C. L. Análise da cadeia de valor e elaboração de políticas industriais: o caso da indústria brasileira de papel de imprimir e escrever para exportação. In: CONGRESSO NACIONAL DE ENGENHARIA DA PRODUÇÃO, 23., 2003, Ouro Preto. Anais... Ouro Preto: ENEGEP, 2003. p. $1-8$.

Competitividade internacional da indústria de papel de imprimir e escrever brasileira sob a ótica da cadeia de valor. 2002. 270 f. Tese (Doutorado em Engenharia de Produção de Sistemas) - Universidade Federal de Santa Catarina, Florianópolis, 2002. 


\section{Apêndice}

Resultados das regressões para estimar a função de demanda de papéis tissue no Brasil.

\begin{tabular}{|c|c|c|c|c|c|c|c|c|}
\hline \multicolumn{2}{|c|}{ Modelo 1} & \multirow{2}{*}{$\begin{array}{c}\text { Constante } \\
-326018,535\end{array}$} & \multirow{2}{*}{$\begin{array}{l}\text { Preço } \\
-3,439 \\
\end{array}$} & \multirow{2}{*}{$\begin{array}{c}\text { Renda } \\
232,440\end{array}$} & \multirow{2}{*}{$\begin{array}{c}\mathrm{R}^{2} \\
0,986\end{array}$} & \multirow{2}{*}{$\begin{array}{l}\text { Teste } \mathrm{F} \\
1132,118\end{array}$} & \multirow{2}{*}{$\begin{array}{c}\begin{array}{c}\text { Teste } \\
\text { Durbin- } \\
\text { Watson }\end{array} \\
0,981\end{array}$} & \multirow{2}{*}{$\begin{array}{c}\text { Teste de White } \\
\text { chi2 } \\
\end{array}$} \\
\hline \multirow{4}{*}{ Dados Normais } & Coeficiente & & & & & & & \\
\hline & Estatística t & $-10,855$ & $-1,473$ & 42,022 & & Prob (F) & & 9,210 \\
\hline & Probabilidade & 0,000 & 0,150 & 0,000 & & 0,000 & & Prob > chi2 \\
\hline & Elasticidade & & $-0,032$ & 2,135 & & & & 0,101 \\
\hline \multirow{4}{*}{$\begin{array}{l}\text { Dados Normais } \\
\text { (correção robusta) }\end{array}$} & Coeficiente & $-326018,535$ & $-3,439$ & 232,440 & \multirow[t]{4}{*}{0,986} & 1132,118 & \multirow[t]{4}{*}{0,981} & \\
\hline & Estatística t & $-8,410$ & $-1,280$ & 33,900 & & Prob (F) & & \\
\hline & Probabilidade & 0,000 & 0,211 & 0,000 & & 0,000 & & \\
\hline & Elasticidade & & $-0,032$ & 2,135 & & & & \\
\hline \multirow{4}{*}{$\begin{array}{l}\text { Dados Normais } \\
\text { (diferenças) }\end{array}$} & Coeficiente & 17786,270 & $-0,809$ & 75,923 & \multirow[t]{4}{*}{0,986} & 1132,118 & \multirow[t]{4}{*}{1,623} & chi2 \\
\hline & Estatística t & 3,040 & $-0,340$ & 2,050 & & Prob (F) & & 2,110 \\
\hline & Probabilidade & 0,005 & 0,738 & 0,049 & & 0,000 & & Prob > chi2 \\
\hline & Elasticidade & & $-0,007$ & 0,698 & & & & 0,833 \\
\hline \multirow{4}{*}{ Dados em logaritmo } & Coeficiente & 0,016 & $-0,076$ & 1,671 & \multirow[t]{4}{*}{0,970} & 541,219 & \multirow[t]{4}{*}{0,931} & chi2 \\
\hline & Estatística t & 0,025 & $-2,327$ & 29,802 & & Prob (F) & & 12,84 \\
\hline & Probabilidade & 0,980 & 0,026 & 0,000 & & 0,000 & & Prob > chi2 \\
\hline & Elasticidade & & $-0,076$ & 1,671 & & & & 0,0250 \\
\hline \multirow{4}{*}{$\begin{array}{c}\text { Dados em logaritmo } \\
\text { (correção robusta de } \\
\text { White) }\end{array}$} & Coeficiente & 0,016 & $-0,076$ & 1,671 & \multirow[t]{4}{*}{0,970} & 541,219 & \multirow[t]{4}{*}{0,931} & \\
\hline & Estatística t & 0,020 & $-1,690$ & 30,950 & & Prob $(F)$ & & \\
\hline & Probabilidade & 0,983 & 0,100 & $\begin{array}{l}0,000 \\
\end{array}$ & & 0,000 & & \\
\hline & Elasticidade & & $-0,076$ & 1,671 & & & & \\
\hline
\end{tabular}

Fonte: resultados da pesquisa.

Resultados das regressões para estimar a função de demanda de papéis tissue no Brasil (continuação).

\begin{tabular}{|c|c|c|c|c|c|c|c|c|c|c|}
\hline \multicolumn{2}{|c|}{ Modelo 2} & Constante & Preço & Renda & Tendência & $\mathrm{R}^{2}$ & Teste F & $\begin{array}{c}\text { Teste } \\
\end{array}$ & Teste de White & \\
\hline \multirow{4}{*}{ Dados Normais } & Coeficiente & \begin{tabular}{|l|}
$-257357,699$ \\
\end{tabular} & $-0,437$ & 182,799 & 6043,918 & \multirow[t]{4}{*}{0,988} & 874,483 & \multirow[t]{4}{*}{0,933} & chi2 & \\
\hline & Estatística t & $-6,542$ & $-0,176$ & 8,842 & 2,479 & & Prob (F) & & 16,650 & \\
\hline & Probabilidade & 0,000 & 0,862 & 0,000 & 0,019 & & 0,000 & & Prob $>$ chi 2 & \\
\hline & Elasticidade & & $-0,004$ & 1,679 & 55,526 & & & & 0,055 & \\
\hline \multirow{4}{*}{ Dados em logaritmo } & Coeficiente & 10,766 & $-0,035$ & 0,233 & 0,041 & \multirow[t]{4}{*}{0,986} & 776,189 & \multirow[t]{4}{*}{1,065} & chi2 & \\
\hline & Estatística t & 5,986 & $-1,498$ & 0,984 & 6,151 & & Prob (F) & & 19,970 & \\
\hline & $\begin{array}{l}\text { Probabilidade } \\
\end{array}$ & 0,000 & 0,144 & 0,332 & 0,000 & & 0,000 & & Prob > chi 2 & \\
\hline & Elasticidade & & $-0,035$ & 0,233 & 0,041 & & & & 0,018 & \\
\hline \multicolumn{2}{|c|}{ Modelo 3} & Constante & Preço & Renda & $\begin{array}{l}\text { Consumo } \\
\text { defasado }\end{array}$ & $\mathrm{R}^{2}$ & Teste F & \begin{tabular}{|c|} 
Teste \\
Durbin-Watson
\end{tabular} & Teste de White & \\
\hline \multirow{4}{*}{ Dados Normais } & Coeficiente & $-134572,239$ & $-0,813$ & 95,048 & 0,615 & \multirow[t]{4}{*}{0,995} & 2010,492 & \multirow[t]{4}{*}{\begin{tabular}{|c|}
1,748 \\
\end{tabular}} & chi2 & \\
\hline & Estatística t & $-4,241$ & $-0,549$ & 5,051 & 7,423 & & Prob (F) & & 9,950 & \\
\hline & Probabilidade & 0,000 & 0,587 & 0,000 & 0,000 & & 0,000 & & Prob $>$ chi2 & \\
\hline & Elasticidade & & $-0,007$ & 0,873 & 0,006 & & & & 0,354 & \\
\hline \multirow{4}{*}{ Dados em logaritmo } & Coeficiente & $-0,277$ & 0,011 & 0,435 & 0,744 & \multirow[t]{4}{*}{0,990} & 1086,841 & \multirow[t]{4}{*}{1,760} & chi2 & \\
\hline & Estatística $t$ & $-0,765$ & 0,487 & 2,785 & 8,088 & & Prob (F) & & 14,050 & \\
\hline & Probabilidade & 0,450 & 0,629 & 0,009 & 0,000 & & 0,000 & & Prob $>$ chi 2 & \\
\hline & Elasticidade & & 0,011 & 0,435 & 0,744 & & & & 0,121 & \\
\hline \multicolumn{2}{|c|}{ Modelo 4} & Constante & Preço & Renda & $\begin{array}{l}\text { Consumo } \\
\text { defasado }\end{array}$ & Tendência & $\mathrm{R}^{2}$ & Teste F & \begin{tabular}{|c|} 
Teste \\
Durbin-Watson \\
\end{tabular} & Teste de White \\
\hline \multirow{4}{*}{ Dados Normais } & Coeficiente & \begin{tabular}{|l|}
$-126342,661$ \\
\end{tabular} & $-0,152$ & 89,045 & 0,582 & \begin{tabular}{|l|}
1609,437 \\
\end{tabular} & \multirow[t]{4}{*}{0,995} & 1500,487 & \multirow[t]{4}{*}{1,746} & chi2 \\
\hline & Estatística $t$ & $-3,822$ & $-0,092$ & 4,458 & 6,458 & 0,916 & & Prob (F) & & 17,080 \\
\hline & Probabilidade & 0,001 & 0,927 & 0,000 & 0,000 & 0,367 & & 0,000 & & Prob $>$ chi2 \\
\hline & Elasticidade & & $-0,001$ & 0,818 & 0,005 & 14,786 & & & & 0,252 \\
\hline \multirow{4}{*}{ Dados em logaritmo } & Coeficiente & 2,275 & 0,005 & 0,316 & 0,614 & 0,009 & \multirow[t]{4}{*}{0,991} & 811,812 & \multirow[t]{4}{*}{1,655} & chi2 \\
\hline & Estatística $t$ & 0,820 & 0,222 & 1,563 & 3,666 & 0,928 & & Prob $(\mathrm{F})$ & & 21,380 \\
\hline & Probabilidade & 0,418 & 0,826 & 0,128 & 0,001 & 0,361 & & 0,000 & & Prob > chi2 \\
\hline & Elasticidade & & 0,005 & 0,316 & 0,614 & 0,009 & & & & 0,092 \\
\hline
\end{tabular}

Fonte: resultados da pesquisa.

Teoria e Evidência Econômica - Ano 23, n. 48, p. 118-149, jan./jun. 2017 